UNIVERSIDADE DE SÃO PAULO

INSTITUTO DE QUIMMICA

\title{
APLICAÇÕES ANALITICAS DE COMPLEXOS MISTOS DE HALETOS DE PALÁDIO E PLATINA COM TRIFENILFOSFINA, - ARSINA, - ESTIBINA
}

Orientador:

Prof. Dr. Paschoal Senise

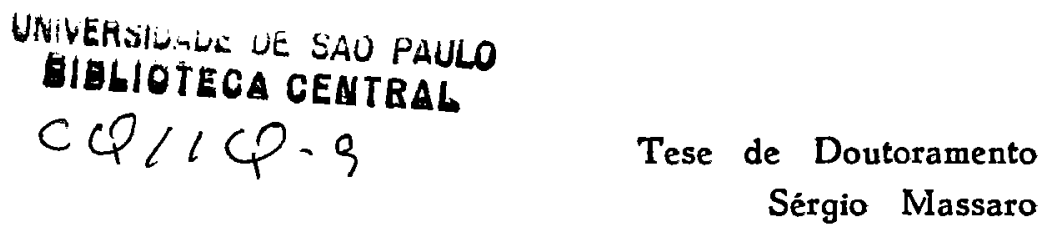


AGRADECIMENTOS

Ao prof. Dr. Paschoal Senise, orientador desta tese, pela confiança em nós depositada.

Aos amigos do Instituto, alunos, funcionários, pro fessores, pelo incentivo e colaboração prestados.

A F.A.P.E.S.P. pela bolsa de estudos concedida. 
Introdução

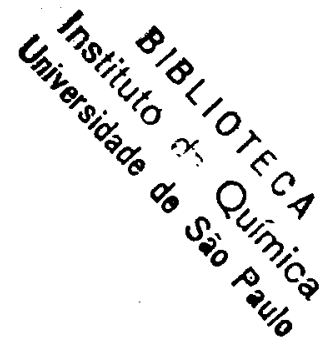

COMPLEXOS MISTOS DE METAIS DE TRANSIÇÃO COM HALETOS E FOSFINAS, ARSINAS, ESTIBINAS

Capitulo I

ESTUDOS PRELIMINARES

Capitulo II

IDENTIFICAÇAO DE MICROQUANTIDADES DE CIANETO

(PROVA DE TOQUE)

Capitulo III

EXTRACCAO E DETERMINAÇÃO ESPECTRO FOTOMËTRICAi DE IODETO

Capítulo IV

Resumo

Bibliografia 
COMPLEXOS MISTOS DE METAIS DE TRANSICỸO COM

HALETOS E FOSFINAS, ARSINAS, ESTIBINAS.

As primeiras sínteses de compostos de adição entre haletos de metais de transição e compostos orgânicos contendo fósforo, arsê nio e antimônio remontam a mais de um século. CAHOURS e GAL (I), por vol ta de 1870, isolaram e analisaram compostos de adição entre os clore tos de paládio, platina e ouro com várias fosfinas e arsinas alifáticas. Devido ao desconhecimento dos pesos atômicos corretos dos elementos pre sentes, os autores sugeriram fórmulas erradas. Todavia os resultados das análises realizadas permitem concluir a formulação correta.

No período que vai desde estas primeiras sinteses até a terceira década de nosso século, poucos dados se encontram na literatura sobre tais compostos; mesmo os raros relatos aparecidos (2-4), se re ferem também a complexos de paládio, platina e ouro que se mantiveram como os únicos conhecidos durante muito tempo.

A década de 30 marca o início de um grande fluxo de trabalhos. MANN e colaboradores, além de prepararem uma série de compostos de paládio (5), caracterizaram compostos de cobre (6) mostrando que são tetrâmeros. JENSEN obteve muitos compostos de platina (7) e caracteri zou complexos de níquel (8) e cobalto (9), indicando as condições em que podem ser preparados.

Nos últimos 30 anos, trabalhos de vários autores contribuíram para sistematizar os conhecimentos sôbre obtenção, estrutura e propriedades desses complexos. Entre êles se destacam os grupos de NYHOLM, CHATT e MANN que prepararam os complexos de muitos metais de transição variando os radicais orgânicos ligados aos elementos de família $V$, inclusive usando moléculas bidentadas, entre as quais se destaca o agente quelante comumente conhecido como diarsina (o-fenilenobis dimetilarsina) que forma complexos muito estáveis (10-13). Também foi estudada a isomeria cis-trans que estes complexos mistos apresentam quan do a coordenação ao redor do íon metálico é plano-quadrada, bem como fo ram discutidos os fatores eletrônicos e termodinâmicos que influem na sua estabilidade e isomerização (14); em alguns casos, graças a diferen 
ças de solubilidade em certos solventes, é possível separar esses isô meros (15).

Dignos de destaque são também os trabalhos de ISSLEB e colaboradores (16-17), que obtiveram vários complexos de fosfinas com metais de transição, sendo que os do início da série, por sua instabili dade, requerem cuidados especiais de preparação.

Com precauções tais como escolha de solventes adequados, VENANZI (18) conseguiu preparar vários complexos, entre os quais alguns que JENSEN (19) tentara obter anteriormente sem sucesso.

Novos compostos também foram preparados ou tiveram sua $\underline{e}$ xistência indicada por COTTON (20), WILKINSON (21-22), HAITFIELD (23) e outros autores. A tabela ol reune as referências julgadas mais importan tes, que indicam as sinteses de tais compostos para os diversos metais.

Publicações sobre complexos contendo fosfinas como ligan tes têm sido ininterruptas, por causa do interesse despertado pela esta bilização de situações incomuns, tais como baixos números de oxidação de metais (37), compostos com ligantes como hidretos (38-39) ou grupos orgânicos diretamente coordenados (40-41), fixação de nitrogênio (42), pentacoordenação (43); êsses compostos se prestam bastante a estudos sô bre a cinética de reações dos complexos dos metais de transição (44) e também a estudos estruturais através da ressonância nuclear magnética (45). Outro fator que por si só explicaria a grande importância desse tipo de complexos é a sua atividade catalítica para um grande número de reações de moléculas orgânicas (82).

BОOTH (46) apresenta uma resenha dos conhecimentos sôbre êste tipo de compostos e tece importantes considerações de ordem geral.

Quanto ao aspecto preparativo, observa que os complexos dos metais do início das séries de transição só são preparados com o uso de solventes inertes, o que não acontece com os metais do final das séries, que se formam mesmo ao se partir de meio aquoso. Segundo o au tor citado, o principal fator explicativo deste fato, relaciona-se inti mamente com a classificação de PEARSON (47) dos ácidos e bases de Lewis em "moles" e "duros".

Tem sido amplamente aceito o modelo segundo o qual fosfi nas e estibinas, assim como as aminas, ligam-se aos metais através de 


\begin{tabular}{|c|c|c|c|c|}
\hline \multirow{8}{*}{ 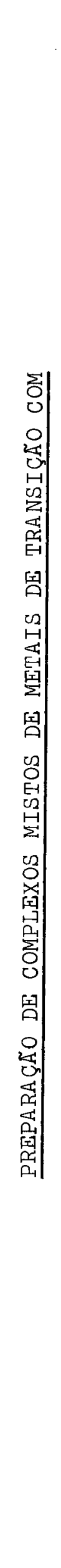 } & \multirow{8}{*}{ 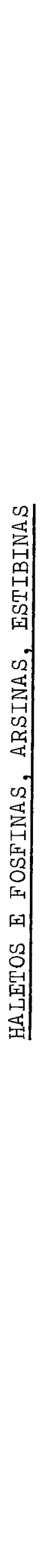 } & 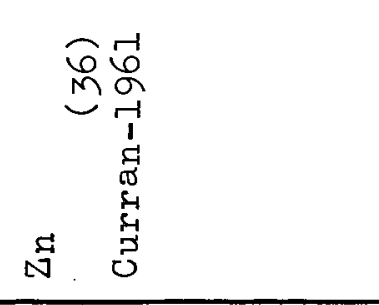 & 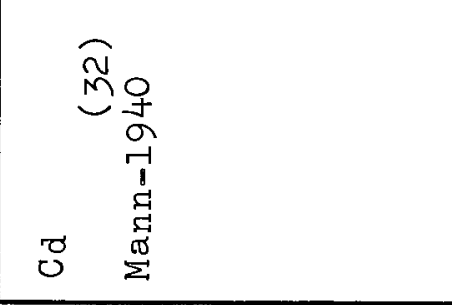 & 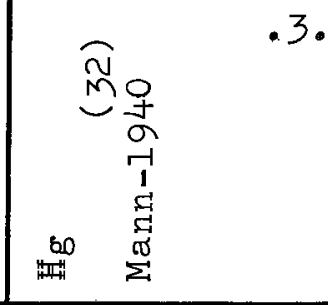 \\
\hline & & 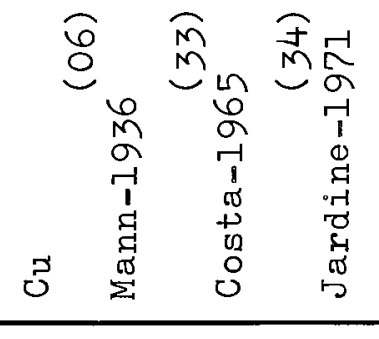 & 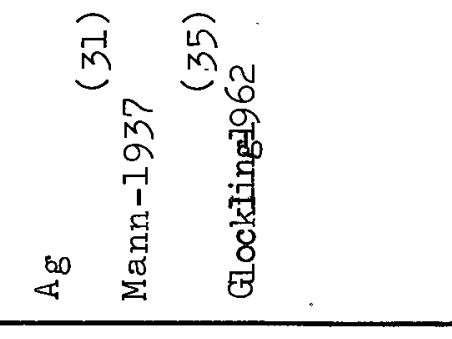 & 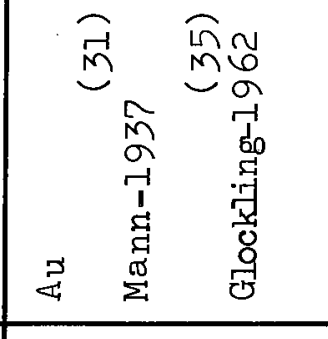 \\
\hline & & 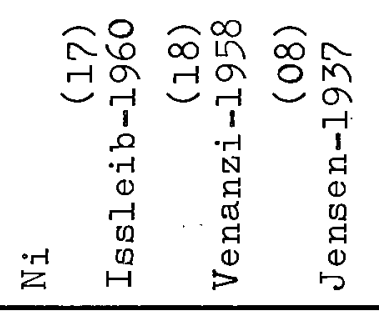 & 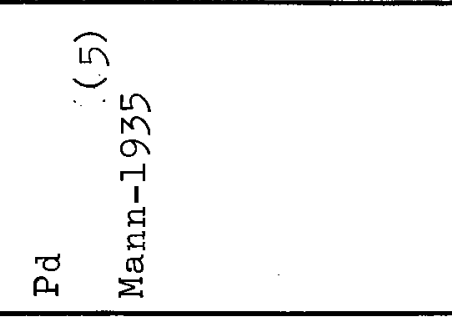 & 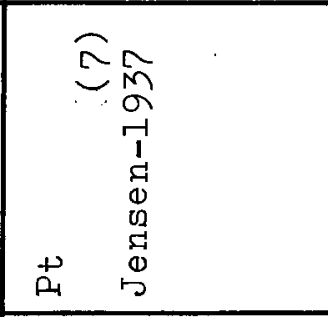 \\
\hline & & 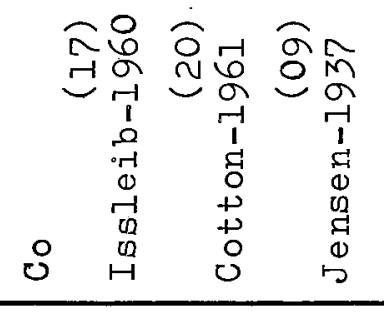 & 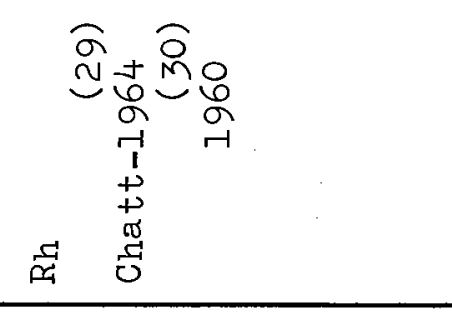 & 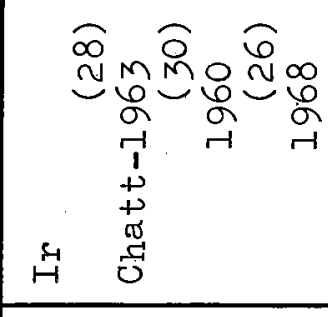 \\
\hline & & 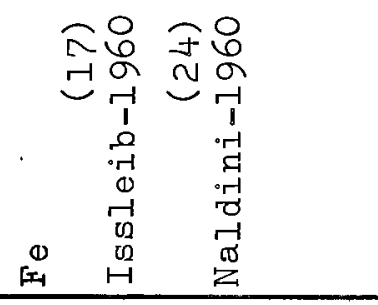 & 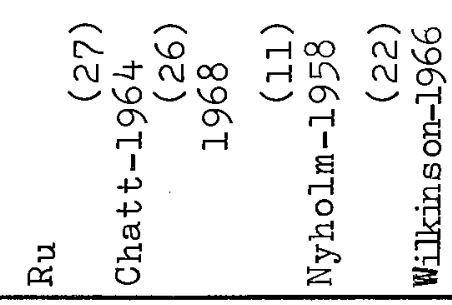 & 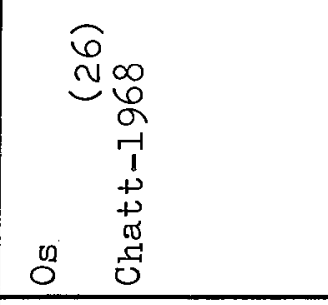 \\
\hline & & 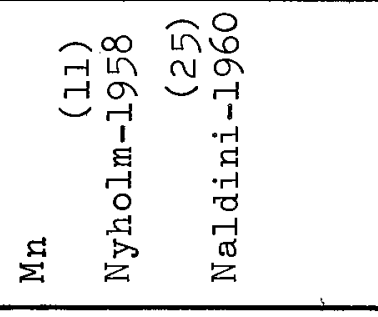 & & 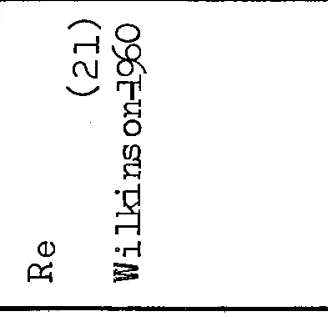 \\
\hline & & 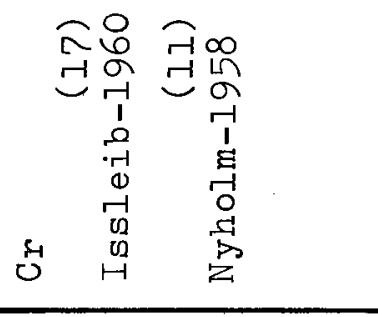 & 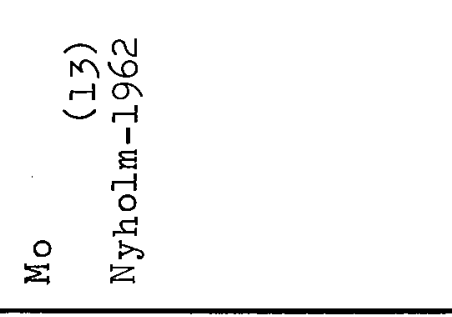 & \\
\hline & & 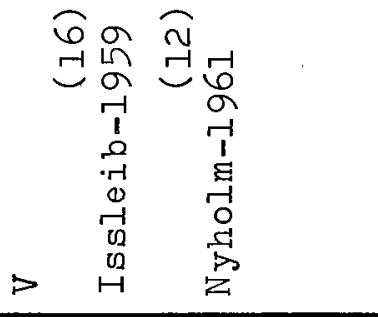 & & \\
\hline
\end{tabular}


uma ligação $\sigma$ "dativa" do ligante para o metal. Mas ao contrário do ni trogênio das aminas, os elementos fósforo, arsênio e antimônio possuem orbitais d vazios quie têm energia e simetria apropriadas para interagirem com orbitais d cheios do metal, através de uma ligação $\underline{\pi}$ "dativa" do metal para o ligante ("retrodoação"). Segundo PEARSON, fósforo, arsê nio e antimônio formam bases moles, ao contrário do nitrogênio que tende a formar bases duras.

Estes fatos desempenham papel fundamental na estabilidade dos complexos. Os metais do início das séries de transição não con tém ou contém poucos elétrons em orbitais $d$, possíveis de serem "retrodoados" aos orbitais $\underline{\text { d }}$ vazios dos ligantes; são porisso ácidos duros.A $\underline{\underline{s}}$ sim neste caso, a estabilidade dos complexos depende principalmente da doação dos elétrons do ligante para o metal, através de uma ligação $\sigma$, ou seja, depende fundamentalmente da basicidade do ligante. Como fosfinas, arsinas e estibinas são muito pouco básicas é bastante natural que seus complexos sejam fracos, impossíveis de serem formados e decompos tos facilmente em presença de solventes doadores de pares eletrônicos (solventes básicos), que competem com vantagem.

Já os metais do final das séries de transição, contendo muitos elétrons d - ácidos moles, segundo PEARSON - dão complexos estáveis com bases moles, o que tem sido justificado em grande parte pela possibilidade de "retrodoação".

Outro fator a que se tem atribuído importância é a grande força do campo ligante causado pelas fosfinas. Os complexos destes ligantes apresentam grande diferença entre os níveis energéticos dos gre pos em que se subdividem os orbitais d do metal de transição. Deste modo êles serão mais estabilizados no campo cristalino ao possuírem os ní veis de baixa energia completos e os níveis de alta energia vazios.

Dentre os complexos mistos de metais com haletos e pseudohaletos e fosfinas, arsinas e estibinas, sem dúvida estão entre os mais estáveis e característicos os formados por paládio (II) e platina(II). Foram durante muito tempo, juntamente com os de ouro (I), os úni cos conhecidos.

São facilmente formados pela reação dos halogeno-complexos dos metais com o reagente orgânico em meio aquoso-etanólico (5), ou mesmo em sistemas de duas fases (água-benzeno por exemplo) (48). Ao con 
trário de outros metais, os rendimentos são altos, sendo muitas vezes sua preparação quantitativa, pelo menos sob o ponto de vista do metal. São bem cristalizados e apresentam pontos de fusão característicos (46).

Isso levou MANN e colaboradores (49-50) a utilizarem fre quentemente os sais $\mathrm{PdCl}_{2}$ e $\mathrm{PdBr}_{2}$ para a caracterização de compostos or gânicos dos elementos da família $V$.

Por outro lado, o fato desses complexos serem facilmente solúveis em muitos solventes organnicos, produzindo soluções coloridas, torna-os propícios para a extração dos metais de soluções aquosas e sua subșequente determinação espectrofotométrica.

Estudos de SENISE e LEVI (51-52) conduziram a seleção de condições onde o paládio é identificado e determinado em reação pratica mente especifica com iodeto e trifenilarsina, a formação do complexo cor respondente de platina sendo inibida por sulfito. Em outras circunstâncias, paládio e platina são determinados conjuntamente pela formação de seus complexos com iodeto e trifenilestibina (48). 


\section{ESTUDOS PRELIMINARES}

\section{A. Extratibilidade de Metais de Transição}

Nós trabalhos citados sôbre a formação e extratibilidade de complexos mistos, são indicadas algumas influências da variação de alguns fatores como: a natureza dos ânions complexantes, a natureza e concentração dos ligantes orgânicos, o solvente empregado na extração $(48.51)$.

Todavia tais influências não estavam suficientemente caracterizadas para os diversos metais, ao iniciarmos nossos trabalhos. A $_{\underline{S}}$ sim, julgou-se interessante efetuar um estudo sistemático da interação de diversos íons de metais de transição com haletos e pseudohaletos e fosfinas, arsinas e estibinas em vários solventes orgânicos. Neste capí tulo são apresentados e discutidos sumariamente os resultados obtidos.

A tabela 11 indica as espécies que foram objeto de estudo.

O Ion metálico $\mathrm{M}$ é tratado com o ligante $\mathrm{X}$; haleto ou pseudohaleto, na fase aquosa. O ligante $\mathrm{ER}_{3}$. (fosfina, arsina, estibina) está na fase orgânica que é equilibrada com a fase aquosa."Verifica-se se o metal passà à fase orgânica na forma de composto de fórmula geral $\mathrm{MX}_{\mathrm{n}}\left(\mathrm{ER}_{3}\right) \mathrm{m}:$

Dentre todas as combinações possíveis, são observados constantemente extratos coloridos apenas com o paládio em condições jả indicadas por LEVI (48). A platina também muitas vezes produz extratos, principalmente nos casos onde se usa a trifenilestibina e, de modo ge ral, quando se utilizam altas concentrações de ligantes na fase orgânica. Os extratos obtidos devem conter sempre o complexo de platina (II) visto que os ligantes orgânicos reduzem a platina (IV) (46). Nessas con dições o ouro também passa à fase orgânica mas é imédiatamente descorado. De acordo com experiências efetuadas por MANN (31), este fato indica a redução de ouro (III) para ouro (I).

Outras formações de extratos contendo metais são apenas esporádicamente verificadas. As mais características são: 
ESPECIES SUBMETIDAS A ESTUDO SISTEMATICO

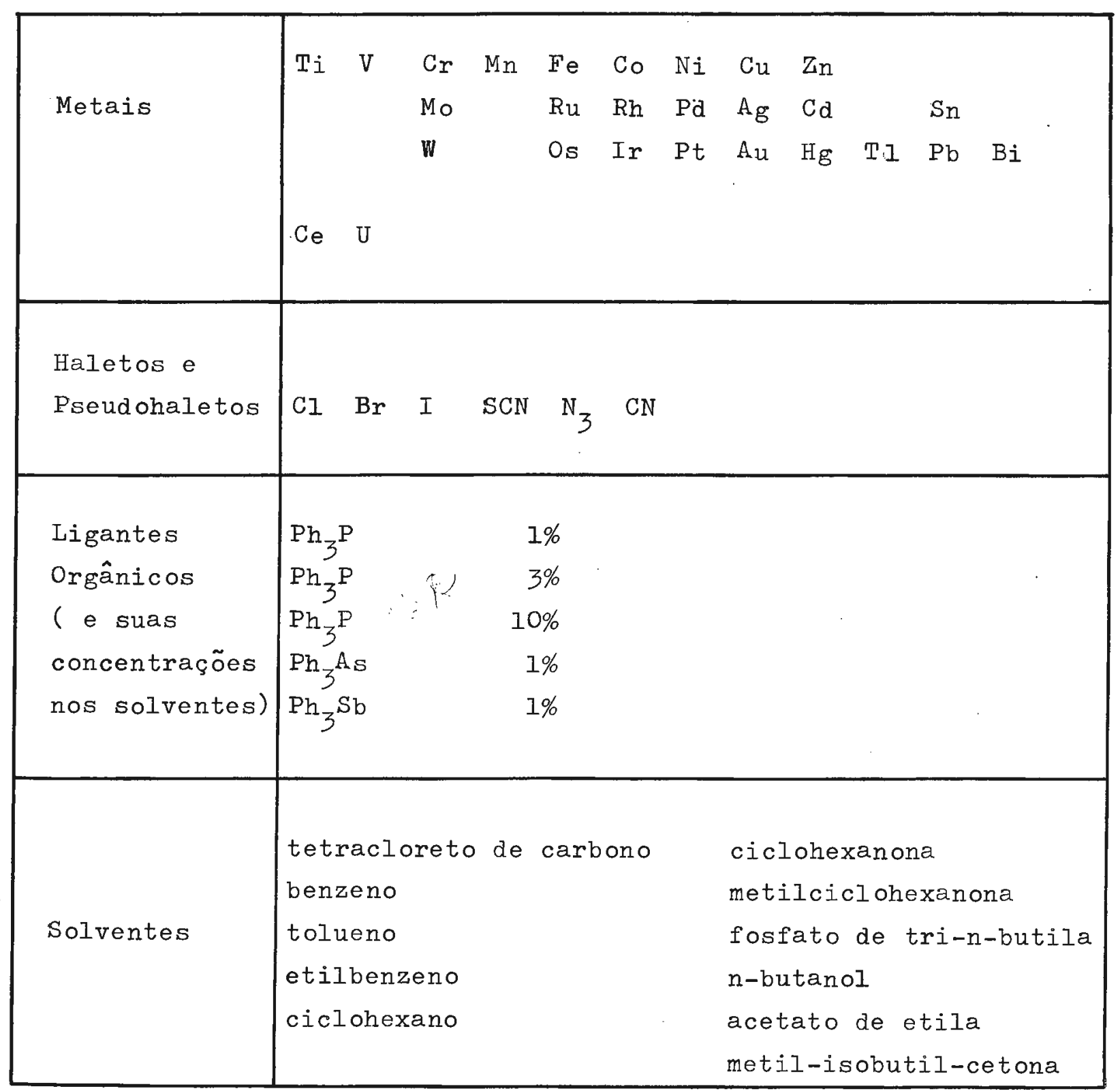


(a) com ródio ao serem utilizados iodeto e trifenilfosfi na - extrato amarelo (a quente).

(b) com ósmio ao serem utilizados brometo (ou tiociana to) e altas concentrações de trifenilfosfina - extrato avermelhado.

(c) com cobalto, tiocianato e trifenilfosfina - extrato

verde.

Tais extrações porém em nenhuma condição foram efetuadas de modo quantitativo, sobrando sempre o metal na fase aquosa em teores bastante significativos.

Frequentemente, inclusive nos casos acima, aparecem depó sitos de sólidos na interface água-solvente orgânico. Este fato ocorre, principalmente, com altas concentrações do ligante orgânico e com aquecimento. Provavelmente são compostos pouco solúveis, formados em pequeno rendimento, comumente citados em preparações do gênero (ver as referências da Introdução).

Ao ser usado o tiocianato como agente complexante há cons tante aparecimento de colorações amarelas na fase orgânica. MAGEE e colaboradores (53), em condições bem próximas às por nós estudadas, ex traiu e determinou platina e ródio, depois de separar o paládio por extração prévia em tetracloreto de carbono, na forma de complexo misto com piridina e tiocianato. Não conseguimos repetir tais extrações, mas verificamos que em meio ácido, a quente, a solução de tiocianato inde pendentemente da presença de íons metálicos ou das moléculas orgânicas, se transforma em um sólido amarelo, já anteriormente descrito (54), solúvel em alguns solventes orgânicos como a metil-isobutil-cetona.

Sob o aspecto dos ligantes orgânicos é nítida a maior fa cilidade de serem formados e extraidos os complexos com trifenilfosfina, relativamente aos de trifenilarsina e trifenilestibina, decrescendo a estabilidade nesta ordem, como seria de se esperar (46). LEVI já observara que a adição de fosfina sôbre os complexos de paládio com arsina e estibina em solução benzênica, os destrói para formar o fosfina comple xo, mais estável (48).

Quanto aos solventes utilizados, os extratos obtidos a partir de paládio e platina são mais estáveis se o solvente é aromático em lugar de outros hidrocarbonetos, os quais frequentemente apresentam 
depósitos de sólidos.

Ao serem utilizados solventes "doadores", com maior po der de extração (álcoois, ésteres, cetonas) de modo geral não se verifi cam diferenças marcantes com relação aos solventes "inertes" (hidrocarbonetos em geral). Isto indica que os complexos formados se assemelham aos do tipo "coordenação saturada" segundo a classificação de ALIMARIN (55). Deve-se notar que em vários casos há extrações com o uso de sol ventes oxigenados, nas condições em que solventes inertes não extraem. Nestes casos porém a extração é independente da presença do ligante orgânico, fosfina ou correlato, indicando que os compostos extraídos de vem ser de outra natureza.

Esse conjunto de observações fornece um suporte experi mental mais completo a conclusão de que nas condições que indicamos,par tindo de fase aquosa contendo o halogeno-complexo metálico e adicionant do o outro ligante dissolvido em um solvente orgânico, a formação de cơm plexos (coloridos) só ocorre de maneira facilmente aproveitável para fins analíticos, com o paládio e, em determinadas condições, com a platina. Outros metais não dão, nestas circunstâncias, extratos diretamente utilizáveis segundo objetivo analítico.

Deve ser ressaltado que conclusões bem parecidas foram paralelamente obtidas por PITOMBO (56) ao estudar a classe dos compos tos da familia VI ( $S, S e, T e)$. Por outro lado, alguns autores (57-59) também já estudaram extrações em sistemas deste tipo, tendo como ligantes a piridina ou sulfetos orgânicos e usando técnicas de observação independentes da cor do extrato orgânico, tais como absorção atômica ou traçadores radioativos.

\section{B. Possibilidades Analiticas}

O uso analítico de complexos mistos de metais de transição com haletos ou pseudohaletos e molẻculas orgânicas contendo elemento da família $V$, não se esgota todavia com a possibilidade de determi nar os metais.

Já que alguns complexos tề sua formação facilmente conseguida e são bem caracterizados, qualquer alteração, nessas condições, provocadas por espécies químicas estranhas pode, a rigor, ser aproveita da. 
Procuramos assim focalizar nossa atenção no comportamento dos ânions (haletos'e pseudohaletos) complexantes para poder tirar daí algumas aplicações analíticas.

Assim em primeiro lugar, o fato de ions cianeto inibirem a formação de complexos mistos de paládio, nos levou a elaboração de uma prova de toque para esse pseudohaleto. Em segundo lugar, a formação de complexos e subsequente extração de platina, a partir de fase aquosa contendo platina (IV), foi notada ocorrer, em determinadas condições, so mente na presença de iodeto e não em presença de cloreto e brometo; isto permite a determinação seletiva do primeiro haleto citado. Por fim, alguns azido-complexos mistos submetidos a monóxido de carbono transfor mam-se nos correspondentes isocianato-complexos, com mudança das características espectrais, o que sugeriu o desenvolvimento de um método para dosagem espectrofotométrica de monóxido de carbono.

\section{Detalhes Experimentais}

O procedimento geral seguido nos ensaios destes estudos preliminares foi o seguinte:

" A uma gota de solução do sal do metal em um microtubo adiciona-se uma gota de solução do haleto. Aquece-se ou espera-se alguns minutos para que a complexação se efetue. Adicionam-se gotas do solvente contendo o ligante orgânico e agita-se. Deixa-se em repouso ou centrifuga-se para separar as fases e verificar se há coloração na fase orgânica. Se a observação for negativa, aquece-se ligeiramente para tentar a extração a quente, e repete-se a observação."

Nota 1. Em alguns casos há dificuldades em se verificar pela cor se houve ou não extração do metal, tendo-se que recorrer ao au xílio de reagentes. A tabela 12 indica os metais para os quais assim se procedeu e os reagentes utilizados (60).

Nota 2. Em casos de difícil formação de complexo com o haleto ou pseudo-haleto reagente, evaporou-se a solução original do metal (via de regra o cloro-complexo) várias vezes com ácido perclórico, só depois tendó́se adicionado o ligante inorgânico. Este procedimento foi também adotado quando se suspeitou da presença de complexos mistoscloro-halogeno ou cloro-pseudohalogeno-complexos - que pudessem condu - 
REAGENTES UTILIZADOS NA DETERMINAÇAO DE METAIS $(60)$

\begin{tabular}{|l|l|}
\hline \multicolumn{1}{|c|}{ Reagente } & \multicolumn{1}{|c|}{ Metais } \\
\hline ditizona & $\mathrm{Bi}, \mathrm{Cu}, \mathrm{Ag}, \mathrm{Pb}, \mathrm{Te}$ \\
ácido 8-hidroxiquinolina-5-sulfonico & $\mathrm{Zn}, \mathrm{Cd}$ \\
sulfeto de sódio & $\mathrm{Hg}$ \\
cloreto de estanho (II) & $\mathrm{Rh}, \mathrm{Pt}$ \\
cloreto de estanho (II)-brometo & $\mathrm{Ir}$ \\
cloreto de estanho (II)-tiocianato & $\mathrm{W}$ \\
tiocianato de sódio & $\mathrm{Ru}, \mathrm{Os}, \mathrm{Mo}$ \\
água oxigenada & $\mathrm{Ti}, \mathrm{V}$ \\
ferrocianeto & $\mathrm{U}$ \\
\hline
\end{tabular}

zir a observações enganosas. Depois deste prévio tratamento, prosseguiu se normalmente.

$$
\text { Nota 3. A tabela } 13 \text { indica alguns solventes para }
$$
quais o procedimento habitual foi modificado.

\section{TABELA 13}

SOLVENTES PARA OS QUAIS HOUVE MUDANÇA DE PROCEDIMENTO
Ciclohexanona
Metil-ciclohexanona
Fosfato de tri-n-butila
Acetato de Etila
n-butanol
Metil-isobutil-cetona 
.12 .

Nestes casos adicionou-se o reagente orgânico em solução etanólica ou sólido; aqueceu-se ligeiramente por alguns minutos e só de pois adicionou-se o solvente para tentar a extração.

\section{Soluções Utilizadas}

METAIS. Soluções contendo $500 \mathrm{\mu g} /$ gota do elemento na for ma de seus cloro- ou aquo-complexos, preparado por pesagem direta do sal comercial P.A. e diluição conveniente.

HALETOS e PSEUDOHALETOS. Soluções dos sais de sodio a $20 \%$ (massa / volume).

SOLVENTES. Purificados por destilação simples. 


\section{IDENTIFICAÇAO DE MICROQUANTIDADES DE CIANETO}

\section{(Prova de Toque)}

\section{A. Introducão}

E conhecido que os íons cianeto formam com o paládio um complexo incolor e muito eståvel $\mathrm{Pd}(\mathrm{CN})_{4}{ }^{2-}$, que resiste mesmo ao tra tamento com ácidos fortes, produzindo a espécie $\mathrm{H}_{2} \mathrm{Pd}(\mathrm{CN})_{4}$ (6I).

Em concordância com isto, SENISE e LEVI (48.51-52), ao es tudarem a interferência de íons estranhos na formação de complexos colo ridos entre paládio, iodeto e trifenilarsina ou trifenilestibina, verificaram que a presença de cianeto impede completamente a coordenação destes Iigantes para dar $\mathrm{PdI}_{4}{ }^{2-}, \mathrm{PdI}_{2}\left(\mathrm{Ph}_{3} \mathrm{Sb}\right)_{2}$ ou $\mathrm{PdI}_{2}\left(\mathrm{Ph}_{3} \mathrm{As}_{2}\right)_{2}$.

Com apoio nestes fatos procurou-se elaborar um método se letivo, fácil e rápido para identificação de cianeto, baseado no descoramento que os complexos avermelhados formados entre paládio, iodeto e trifenilestibina sofrem na presença desta espécie.

\section{B. Papel Reagente e sua Caracterização}

A fim de facilitar a execução da prova para cianeto, pro curou-se preparar um papel-reagente colorido contendo os complexos cita dos anteriormente, segundo técnicas preconizadas por FEIGL (62-63) : o papel absorve soluções que ao evaporarem deixam o soluto impregnado sob forma finamente dividida, utilizada para reaçoses de toque de sensibilidade bastante aumentada. Tal papel descorará quando submetido a gotas de solução ou vapores contendo cianeto.

Várias alternativas foram tentadas para o preparo do papel; dentre elas destacamos as seguintes:

(a) imersão em solução aquosa de $\mathrm{PdI}_{4}{ }^{2-}$ e posterior se cagem;

(b) imersão em solução benzênica de $\mathrm{PdI}_{2}\left(\mathrm{PH}_{3} \mathrm{Sb}\right)_{2}$ e pos terior secagem; 
(c) imersão prévia em solução aquosa de $\mathrm{PdI}_{4}{ }^{2-}$, secagem, posterior imersão em solução benzênica de $\mathrm{Ph}_{3} \mathrm{Sb}$ seguida de secagem final.

A alternativa (a) foi logo descartada ao se verificar que por ser o iodo-paladato hidrossolúvel, o simples contacto com soluções ou vapores aquosos torna heterogênea a coloração do papel, desaconselhan do assim sua utilização.

A alternativa (c) é a mais indicada devido a maior sensí bilidade conseguida na deteç̧ão de pequenos teores de cianeto. 0 papel reagente assim preparado apresenta um tom vermelho mais escuro que. na alternativa (b), aproximando-se do papel preparado como em (a) e requer preparação mais complexa que necessita de maiores cuidados.

Os espectros de reflexão desses diversos papeis foram com parados entre si e com o espectro de absorção de soluções benzênicas de $\mathrm{PdI}_{2}\left(\mathrm{Ph}_{3} \mathrm{Sb}\right)_{2}$ (Veja figura I).

Enquanto o papel preparado com em (b) apresenta espectro idêntico ao da solução benzênica, indício de que contém o composto $\mathrm{PdI}_{2}\left(\mathrm{Ph}_{3} \mathrm{Sb}\right)_{2}$, o papel preparado em conformidade com o descrito em (c) apresenta espectro que se aproxima mais do espectro do papel preparado de acordo com a técnica indicada em (a), ou mais precisamente, a uma combinação dos espectros dos papeis (a) e (b). Isso nos induz a imagi nar que o papel escolhido para a prova de toque, preparado segundo o procedimento (c), contenha o complexo $\mathrm{PdI}_{2}\left(\mathrm{Ph}_{3} \mathrm{Sb}\right)_{2}$ formado na superfí cie do iodopaladato de sódio que impregna em primeiro lugar o papel.

Tal suposição encontra apoio em alguns fatos:

Iㅇ) O papel preparado segundo a alternativa (b) é bastan te descorado ao ser banhado em benzeno, enquanto o papel preparado segundo (c) não o é;

20) O papel (a) submetido a solução benzênica de $\mathrm{Ph}_{3} \mathrm{Sb}$ somente em alguns pontos e seco, sendo lavado exaustivamente com água, descora exceto nos locais onde foi aplicada a solução de trifenilestibị na. 

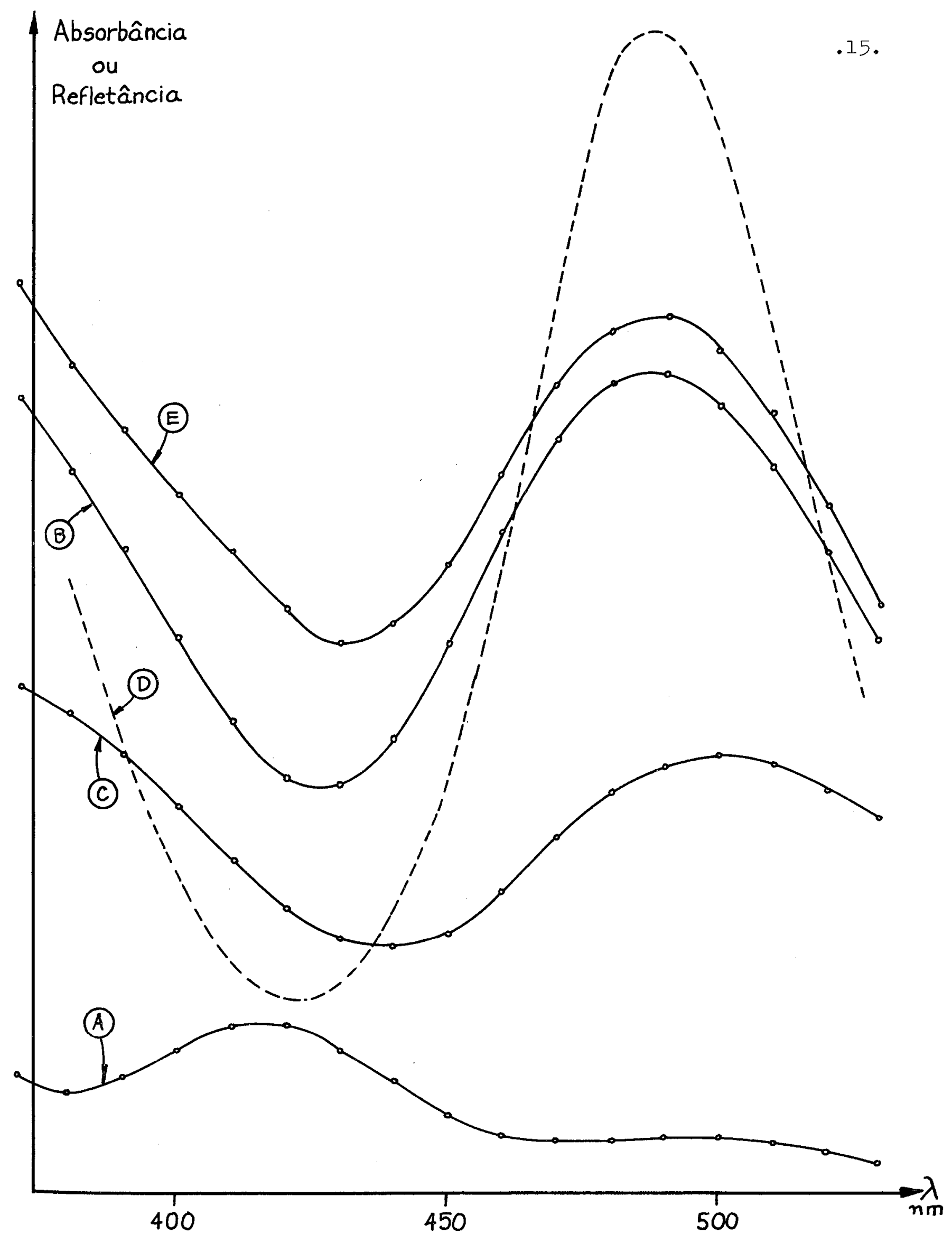

GRÁFICO_I

Espectros das espécies destruíidas por c cianeto

Curvas $A, B, C$, espectros de reflexão (A: papel-preparado com $\left[\mathrm{PdI}_{4}\right]^{2-} ; \mathrm{B} ;$ papel-preparado com $\left[\mathrm{PdI}_{2}\left(\mathrm{Ph}_{3} \mathrm{Sb}\right)_{2}\right] ; \mathrm{C}$ : papelreagente.) Curva $\mathrm{D}$ : espectro de absorção de $\left[\mathrm{PdI}_{2}\left(\mathrm{Ph}_{3} \mathrm{Sb}\right)_{2}\right]$ em benzeno. Curva E: combinação das curvas A e B. 


\section{Elaboração do Procedimento e Estudo de Interferências}

Para a reạ̣ização do teste a princípio gotejávamos a solução em análise para cianeto söbre o papel reagente e observávamos o seu descoramento. Posteriormente na realização do teste em presença de outros íns, foi verificado ser mais conveniente o recolhimento do cianeto de hidrogênio, HCN gasoso, desprendido pelo tratamento da amostra com ácido, sôbre papel reagente umedecido com uma solução tampão adequa da. Esse passou a ser nosso procedimento básico com o qual se verificou que pequenos teores de cianeto podem ser inequivocamente detectados em presença de altas concentrações de um grande número de íons.

Todavia em presença de ânions que em meio ácido tenham $\underline{e}$ levado potencial de oxidação ou que nestas condições desprendam gases que ataquem o papel reagente, deve-se fazer o tratamento da amostra com solução de hidrogenocarbonato, o qual propicia a saída de cianeto de hi drogênio sem diminuir o $\mathrm{pH}$ ao ponto de causar reações indesejáveis (64).

o ion azoteto exigiu procedimento especial, que serviu para eliminá-lo juntamente com alguns ânions redutores que contém enxofre.

Quanto aos cátions, após ter sido efetuado o estudo da sua influência, verificou-se que de modo geral, aqueles que não formam ciano-complexos ácido-resistentes, não constituem interferência.

\section{Preparo do Papel-Reagente}

Papel Whatman no $l$ é rapidamente imerso em solução aquosa de tetraiodo-paladato (II) de sódio (preparada por dissolução de $\mathrm{PdI}_{2}$ recém precipitado em solução de $\mathrm{NaI} 40 \%$ massa/volume) e seco em ja to de ar quente, adquirindo coloração avermelhada. Então é submetido à solução benzênica de trifenilestibina 1\% (massa/volume) e seco novamente. Finalmente é lavado com água e submetido a secagem final.

Observação: A maior sensibilidade é obtida quando a intensidade da coloração deste papel é tal que dê uma reflexão de 65-70\% em $500 \mathrm{~nm}$. 


\section{Procedimento Básico}

Em um microtubo contendo 1 gota da solução em análise adiciona-se $\mathrm{I}$ gota de $\mathrm{H}_{2} \mathrm{SO}_{4} \mathrm{O}, \mathrm{I} \mathrm{N}$ e fecha-se a boca do tubo com um peque no pedaço de papel-reagente umedecido com tampão de borato ( $\mathrm{pH}=9-10$ ). Passados alguns minutos verifica-se o descoramento da parte do papel ex posta aos gases desprendidos, que indica a presença de cianeto. Efetuase em paralelo um teste em branco apenas com os reagentes.

$$
\begin{array}{lr}
\text { Limite de Identificação: } & 0,3 \mu \mathrm{g} \\
\text { Limite de Diluição: } & 1: 170,000
\end{array}
$$

\section{Anions Estranhos}

Procedendo-se como indicado, pode-se identificar inequivocamente $1 \mu \mathrm{g}$ de cianeto na presença de $500 \mu \mathrm{g}$ de cada um dos ânions da tabela 21 .

\section{TABELA 21}

IDENTIFICACGAO DE I $\mu_{\mathrm{g}}$ DE CIANETO NA PRESENCA DE $500 \mu \mathrm{g}$ DE

CADA UM DOS SEGUINTES ANIONS

\begin{tabular}{|cccc|}
\hline $\mathrm{CO}_{3}^{2-}$ & $\mathrm{HPO}_{4}^{2-}$ & $\mathrm{HAsO}_{4}^{2-}$ & $\mathrm{TeO}_{3}^{2-}$ \\
$\mathrm{SO}_{4}^{2-}$ & $\mathrm{H}_{2} \mathrm{BO}_{3}^{-}$ & $\mathrm{ClO}_{4}^{-}$ & $\mathrm{H}_{3} \mathrm{C}-\mathrm{CO}_{2}^{-}$ \\
$\mathrm{NO}_{3}^{-}$ & $\mathrm{SCN}^{-}$ & $\mathrm{MoO}_{4}^{2-}$ & $\mathrm{HCO}_{2}^{-}$ \\
$\mathrm{Cl}^{-}$ & $\mathrm{HPO}_{3}^{2-}$ & $\mathrm{WO}_{4}^{2-}$ & $\mathrm{C}_{2} \mathrm{O}_{4}^{2-}$ \\
$\mathrm{Br}^{-}$ & $\mathrm{H}_{2} \mathrm{PO}_{2}^{-}$ & $\mathrm{VO}_{3}^{-}$ & $\mathrm{C}_{4} \mathrm{H}_{4} \mathrm{O}_{6}^{2-}$ \\
$\mathrm{F}^{-}$ & $\mathrm{HAsO}_{3}^{2-}$ & $\mathrm{SeO}_{3}^{2-}$ & $\mathrm{C}_{6} \mathrm{H}_{5} \mathrm{O}_{7}^{2-}$ \\
\hline
\end{tabular}

Na presença de outros íons o procedimento deve ser modificado como se indica a seguir. 


\section{Modificações do Procedimento Básico}

(a) Na presença dos ânions que estão na tabela 22, substitue-se $\mathrm{O}_{2} \mathrm{SO}_{4} \mathrm{O}, 1 \mathrm{~N}$ por uma solução de hidrogenocarbonato de sódio 2\% (massa/volume) e aquece-se levemente. Nestas condições 1 Hg de ciane to é identificado na presença de $500 \mu \mathrm{g}$ de cada um dos ânions estranhos, constantes da tabela.

\section{TABELA 22}

\section{IDENTIFICAÇAOO DE $1 \mu G$ DE CN NA PRESENÇA DE $500 \mu \mathrm{g}$}

DE CADA UM DOS SEGUINTES ANIONS :

( Reagente: hidrogenocarbonato)

\begin{tabular}{|cccc|}
\hline $\mathrm{CNO}^{-}$ & $\mathrm{ClO}_{3}^{-}$ & $\mathrm{ClO}^{-}$ & $\mathrm{SO}_{3}^{2-}$ \\
$\mathrm{S}_{2} \mathrm{O}_{8}^{2-}$ & $\mathrm{BrO}_{3}^{-}$ & $\mathrm{CrO}_{4}^{2-}$ & $\mathrm{S}^{2-}$ \\
$\mathrm{NO}_{2}^{-}$ & $\mathrm{IO}_{3}^{-}$ & $\mathrm{S}_{2} \mathrm{O}_{3}^{2-}$ & \\
\hline
\end{tabular}

(b) $\mathrm{Na}$ presença de azoteto é necessårio efetuar sua eliminação prévia. Trata-se uma gota da solução em análise com solução de iodo $0,1 \mathrm{~N}$ e uma gota de solução 0,05\% de tiossulfato de sódio para induzir a reasăo entre iodo e azoteto (65). Esse tratamento elimina tam bém $\mathrm{S}_{2} \mathrm{O}_{3}^{2-}, \mathrm{SO}_{3}^{2-}$ e $\mathrm{S}^{2-}$ porventura presentes. Acjala-se com ácido ascórm bico 5\% (massa/volume) para reduzir o excesso de iodo que de outro modo atacaria o papel reagente.

\section{Detalhes Experimentais}

Dão-se aqui alguns detalhes que por não serem de funda mental importância à compreensão do estudo, não foram incluídos anteriormente para não sobrecarregar o texto. 


\section{Espectros}

Os espectros de reflexão dos papeis preparados como indi cado na secção B, foram obtidos em um espectrofotômetro Zeiss, modelo PMQ-1O devidamente equipado com os acessórios.

Pedaços dos papeis impregandos com os reagentes colori dos, do tamanho da amostra requerida pelo aparelho, foram diretamente colocados no local apropriado, efetuando-se normalmente as leituras.

o espectro de absorção da solução benzênica de $\mathrm{PdI}_{2}\left(\mathrm{Ph}_{3}\right.$ $\mathrm{Sb})_{2}$ foi obtido no mesmo aparelho.

\section{Soluções e Reagentes}

(a) Cianeto de Sódio. A solução-mãe de NaCN foi preparada com o produto comercial de grau P.A. Uma solução aproximadamente $0,1 \mathrm{~N}$ (130 $\mathrm{\mu g}$ de $\mathrm{CN} / \mathrm{gota}$ ) foi padronizada com solução de prata pelo método de DENIGES (66). Desta solução foram preparadas as soluções utilizadas por diluições convenientes com água destilada previamente fervida para a eliminação de gás carbônico.

(b) Sais Interferentes. São todos produtos P.A. de varia das procedências, dos quais se prepararam diretamente as soluções utili zadas.

Os cianatos comercialmente disponíveis apresentam aprecí ável decomposição, porisso preparou-se o NaOCN segundo SCATTERGOOD (67) e daí as soluções para verificar sua ação como íon estranho.

(c) Tampão de borato. $4 \mathrm{~g}$ de bórax são diluídos a 11 com água destilada.

\section{E. Considerações Gerais.}

A propriedade dos íons cianeto formarem complexos está veis com muitos metais de transição (68), tem sido bastante utilizada para sua identificação (69). Como exemplos podemos citar as reações já clássicas de formação do azul-da-prússia (70) e o teste com acetato de cobre e benzidina (7I) que aproveitam a grande estabilidade dos ciano -complexos de $\mathrm{Fe}(I I)$ e $\mathrm{Cu}(I)$ respectivamente. 
Usando este mesmo princípio, várias determinações de cia neto têm sido conseguidas: a formação dos ciano-complexos estáveis "mas cara" o íon metálico, sendo apenas o seu excesso determinado por reagen tes de menor poder de complexação. Dentre os inúmeros exemplos de deter minações assim efetuadas (69) temos as dosagens elaboradas por OHLWEILER e MEDITSCH que adicionam mercurio (II) e determinam seu excesso com difenilcarbazona (72) ou p-dimetilaminobenzilideno rodanina (73).

Determinações diretas de cianeto pela formação de comple xos são, ao contrário, bastante escassas. A resenha de $B \wedge R K$ e HIGSON (69) cita apenas o trabalho de SCHILT (74) (complexo misto de ferro (II) com fenantrolina e cianeto). Recentemente SCOGGINS (75) usa o complexo com níquel para determinar diretamente, por via espectrofotométrica, o cianeto.

Maior número de aplicações têm sido conseguidas, porém, $\underline{u}$ sando a grande capacidade de complexação de cianeto para a destruição de complexos, geralmente de paládio, mercúrio ou prata. A mudança de cor ou a identificação do ligante liberado por sensíveis reações, permi tem identificar e mesmo dosar o cianeto.

Assim FEIGL e FEIGL (76) destroem o complexo bis(dimetil glioxima)-paládio e identificam a dimetilglioxima com íons de níquel. 0 complexo de mercúrio com 4-(2-piridilazo)resorcinol (PAR) è destruído por cianeto e a mudança de cor aproveitada para identificá-lo em sensivel teste elaborado por LJIS e colaboradores (77). HUMPHRAI e HINZE (78) destroem o complexo insolúvel cloranilato de mercúrio com cianeto, e a a absorção do ânion cloranitato solúvel, libertado é usada para a dosagem indireta. Outro complexo de mercúrio com difenilcarbazida de cor azul, é utilizado por TANAKA e YAMAMOTO (79) para a identificação de cia neto e é também adaptado para dosagens semiquantitativas. TOMKOWIACK (80) utiliza para os mesmos fins o descoramento do complexo de prata com ditizona, de cor violeta.

Nosso teste se enquadra nesta última categoria, visto basear-se no descoramento que os complexos vermelhos de paládio com iodeto e trifenilestibina, sofrem na presença de cianeto de hidrogênio, sen do comparável aos referidos.

Embora percam em sensibilidade para alguns métodos ins trumentais e outros baseados na síntese de KBnig (piridina + amina aro- 
mática + CNBr - corante) (69), estes testes são os de execução mais simples, rápida e digna de confiança, tendo sido mesmo, como visto, a daptados algumas vezes para dosagens semiquantitativas.

No caso do complexo por nós estudado, o fato de ter sido preparado um papel-reagente propicia tê-lo sempre à mão em forma imedia tamente utilizável. Aliando-se a isto as condições em que o cianeto de hidrogênio é desprendido de modo que poucas espécies possam interferir, consegue-se condição bem próxima da ideal (8I) para identificação de pe quenos teores desta espécie. 


\section{EXTRAICAO E DETERMINACGÃO ESPECTROFOTOMETRICA DE IODETO}

\section{A. Estudo Sistemático e Extração Seletiva de Iodeto}

o estudo sistemático da extração de diversos metais de transição na presença de haletos e pseudohaletos e de derivados orgânicos dos elementos superiores da família $V$ da Tabela Periódica mostra al gumas nitidas tendências gerais que concordam com os dados da literatura preparativa para tais compostos, como foi visto na Introdução e nos Estudos Preliminares.

Assim, entre os metais, paládio e platina dão os complexos mais estáveis, caracterísricos e facilmente extraíveis. Fosfinas dão complexos mais estáveis que arsinas e estibinas. Por outro lado os solventes aromáticos extraem melhor e dão soluções mais estáveis dos com plexos do que outros hidrocarbonetos.

Quanto ao comportamento dos complexos obtidos com vários haletos complexantes as observações de ordem geral são mais difíceis. Di ferenças de comportamento entre os diversos haletos são menos nítidas e de modo geral irregulares, de tal maneira que até agora não se tem notí cia da utilização de complexos deste tipo para a diferenciação e separa ção dos ânions。

A este respeito dois aspectos merecem observações. Em primeiro lugar deve-se destacar que de modo geral, as cores dos complexos extraídos se acentuam na série Cl - Br - I o que pode levar engano samente a concluir por uma maior extratibilidade dos iodocomplexos. Por outro lado ânions de grande poder de complexação para metais moles [e no caso se enquadram principalmente paládio (II) e platina (II)] tais como cianeto, tiocianato, azoteto, muitas vezes não dão extratos colori dos permanecendo o metal na fase aquosa. Tal observação já fora efetuada por LEVI (48) no caso do cianeto, fato aliás que deu origem aos trabalhos relatados no segundo capitulo desta tese, mas verificamos ser ex tensiva a outros ânions principalmente quando se trabalha com arsinas ou estibinas que, como é sabido (46), apresentam menor poder de complexação do que as fosfinas. Muito provavelmente, nestes casos os pseudoha 
letos ocupam todas as posições de coordenação do elemento metálico dando origem a espécies carregadas, não extraíveis no solvente orgânico.

Alguns dos fatos mencionados podem ser vistos na tabela 31 que apresentamos como exemplo de observações efetuadas e que mostra dados para a extratibilidade em alguns solventes orgânicos de soluções aquosas de paládio (II) e platina (IV), na presença de alguns haletos e pseudohaletos e de ligantes orgânicos. Visto referir-se a um estudo pre liminar os dados são de natureza meramente qualitativa.

Esta tabela mostra o fato central que deu origem ao méto do para iodeto: ao utilizar-se a platina no seu estado de oxidação mais comum - platina (IV) - não se verifica a formação de extrato em nenhum caso a não ser quando se utiliza o iodeto como íon complexante.

De fato esta foi a primeira observação de nítida diferen ça de comportamento entre os haletos complexantes, que abriu a possibilidade de utilização deste tipo de complexos para a determinação seletị va de ânions.

\section{B. Condições da Reação. Composto Extraído}

Se uma fase aquosa contendo originalmente iodeto e ácido cloro-platínico (IV) for colocada em contacto com uma fase benzênica contendo trifenilestibina, a fase orgânica fica amarela devido à extração de um composto cujo espectro na região do ultravioleta próxima do visível, corresponde ao da espécie $\mathrm{PtI}_{2}\left(\mathrm{Ph}_{3} \mathrm{Sb}\right)_{2}$, já caracterizada e utilizada para a determinação de platina (48).

Foi verificado que o espectro da fase orgânica sempre cor responde ao desta espécie, independentemente da relação entre platina e iodeto existente originalmente na fase aquosa.

Como em trabalhos anteriores $(46.48)$, a redução de plati na (IV) deve acontecer às custas da trifenilestibina, pois a cor do extrato orgânico é proporcional à quantidade de iodeto presente, não havendo desse modo consumo desta espécie redutora, que ao final se encontra totalmente na forma do complexo acima citado. A análise do espectro da fase orgânica também não consegue evidenciar iodo livre ou o produto da reação de iodo com trifenilestibina, que tem absorção nas regiōes do visível e do ultravioleta próximo e que fatalmente surgiriam caso o io- 
TABEIA $\quad 31$

EXTRAÇOES A PARTIR DE SOLUÇOES DE PALÁDIO (II) E PLATINA (IV)

\begin{tabular}{|c|c|c|c|c|c|c|c|c|}
\hline metal & solvente & ligantes & $\mathrm{Cl}$ & $\mathrm{Br}$ & I & $\mathrm{SCN}$ & $\mathrm{N}_{3}$ & $\mathrm{CN}$ \\
\hline \multirow{2}{*}{$\operatorname{Pd}(I I)$} & $\mathrm{C}_{6}{ }^{\mathrm{H}} 6$ & $\begin{array}{l}\mathrm{Ph}_{3} \mathrm{P} \\
\mathrm{Ph}_{3} \mathrm{As}^{\mathrm{S}} \\
\mathrm{Ph}_{3} \mathrm{Sb}\end{array}$ & $\begin{array}{l}+ \\
+ \\
+\end{array}$ & $\begin{array}{l}+ \\
+ \\
+\end{array}$ & $\begin{array}{l}++ \\
++ \\
++\end{array}$ & $\begin{array}{l}+ \\
+\quad * \\
+\quad *\end{array}$ & $\begin{array}{l}+ \\
+* \\
+*\end{array}$ & $\begin{array}{l}0 \\
0 \\
0\end{array}$ \\
\hline & ${ }^{\mathrm{C}} 6^{\mathrm{H}} 12$ & $\begin{array}{l}\mathrm{Ph}_{3} \mathrm{P} \\
\mathrm{Ph}_{3} \mathrm{As} \\
\mathrm{Ph}_{3} \mathrm{Sb}\end{array}$ & $\begin{array}{l}+D \\
+D \\
++\end{array}$ & $\begin{array}{l}+D \\
+D \\
+\end{array}$ & $\begin{array}{l}++ \\
++ \\
++\end{array}$ & $\begin{array}{l}+\mathrm{D} \\
+\mathrm{D} * \\
+\end{array}$ & $\begin{array}{l}+D^{*} \\
+D^{*} \\
+D^{*}\end{array}$ & $\begin{array}{l}0 \\
0 \\
0\end{array}$ \\
\hline \multirow{2}{*}{$\operatorname{Pt}(I V)$} & ${ }^{C_{6}}{ }^{\mathrm{H}_{6}}$ & $\begin{array}{l}\mathrm{Ph}_{3} \mathrm{P} \\
\mathrm{Ph}_{3} \mathrm{As}^{\mathrm{S}} \\
\mathrm{Ph}_{3} \mathrm{Sb}\end{array}$ & $\begin{array}{l}0 \\
0 \\
0\end{array}$ & $\begin{array}{l}0 \\
0 \\
0\end{array}$ & $\begin{array}{l}++\mathrm{D} \\
++\mathrm{D} \\
++\end{array}$ & $\begin{array}{l}+D \\
0 \\
\text { tr }\end{array}$ & $\begin{array}{l}\operatorname{tr} \\
0 \\
0\end{array}$ & $\begin{array}{l}0 \\
0 \\
0\end{array}$ \\
\hline & $\mathrm{C}_{6}{ }^{\mathrm{HI}}{ }_{12}$ & $\begin{array}{l}\mathrm{Ph}_{3} \mathrm{P} \\
\mathrm{Ph}_{3} \mathrm{As}_{5} \\
\mathrm{Ph}_{3} \mathrm{Sb}\end{array}$ & $\begin{array}{l}0 \\
0 \\
0\end{array}$ & $\begin{array}{l}0 \\
0 \\
0\end{array}$ & $\begin{array}{l}+\mathrm{D} \\
+\mathrm{D} \\
+\mathrm{D}\end{array}$ & $\begin{array}{l}0 \\
0 \\
0\end{array}$ & $\begin{array}{l}0 \\
0 \\
0\end{array}$ & $\begin{array}{c}0 \\
0 \\
0\end{array}$ \\
\hline
\end{tabular}

Extração
- nula
D fase orgânica apresenta depósito
tr traços de sólido
+ baixa
++ alta
* fase aquosa colorida após extração 
deto fosse oxidado.

Por outro lado, se na fase aquosa inicial existir platina (II) como reagente, obtem-se idêntico extrato com iodeto. Neste caso também são obtidos extratos a partir de cloreto e brometo, dos corres pondentes complexos com estibina, o que não acontece quando é utilizada a platina (IV).

o ácido cloro-platínico deve estar em excesso sôbre o i으 deto. Desde que em excesso, sua concentração não é crítica, assim como não o é a acidez da fase aquosa e a concentração de trifenilestibina na fase orgânica.

Aparentemente a única inconveniência provém do fato de não ser instantânea a reação da platina (IV) - ou melhor do íon hexaclo ro-platinato-(IV) - com o iodeto como já é conhecido (83). Depois de es tudar a influência do tempo padronizamos a agitação da mistura por 2 ho ras e 30 minutos, na ausência de luz direta, como suficiente para que a reação se complete. Verificou-se que a extração assim efetuada é prati* camente quantilativa visto que a realização de extrações sucessivas não altera a absorbância do extrato.

Os itens seguintes especificam melhor, com dados, o que ficou acima dito em resumo.

\section{Espectro da Espécie Extraída}

Diversas proporções de soluções equimolares de iodeto de sódio e ácido hexacloro-platínico-(IV) foram misturadas e extraídas com soluções benzênicas de trifenilestibina. A figura II mostra os espectros na região de medida analítica (UV próximo) de dois desses extratos contra branco de trifenilestibina em benzeno. Também são fornecidos os es pectros dos compostos $\mathrm{PtI}_{2}\left(\mathrm{Ph}_{3} \mathrm{Sb}\right)_{2}$ (segundo LEVI (48)) e $\mathrm{Ph}_{3} \mathrm{Sb}$, ambos em solução benzênica.

Nem todas as medidas efetuadas nesta série, estão sob as condições estipuladas para o trabalho analítico. o objetivo é mostrar que para quaisquer razões entre platina e iodeto na fase aquosa, o es pectro obtido na. fase orgânica corresponde sempre ao da espécie $\mathrm{PtI}_{2}$ $\left(\mathrm{Ph}_{3} \mathrm{Sb}\right)_{2}$. 


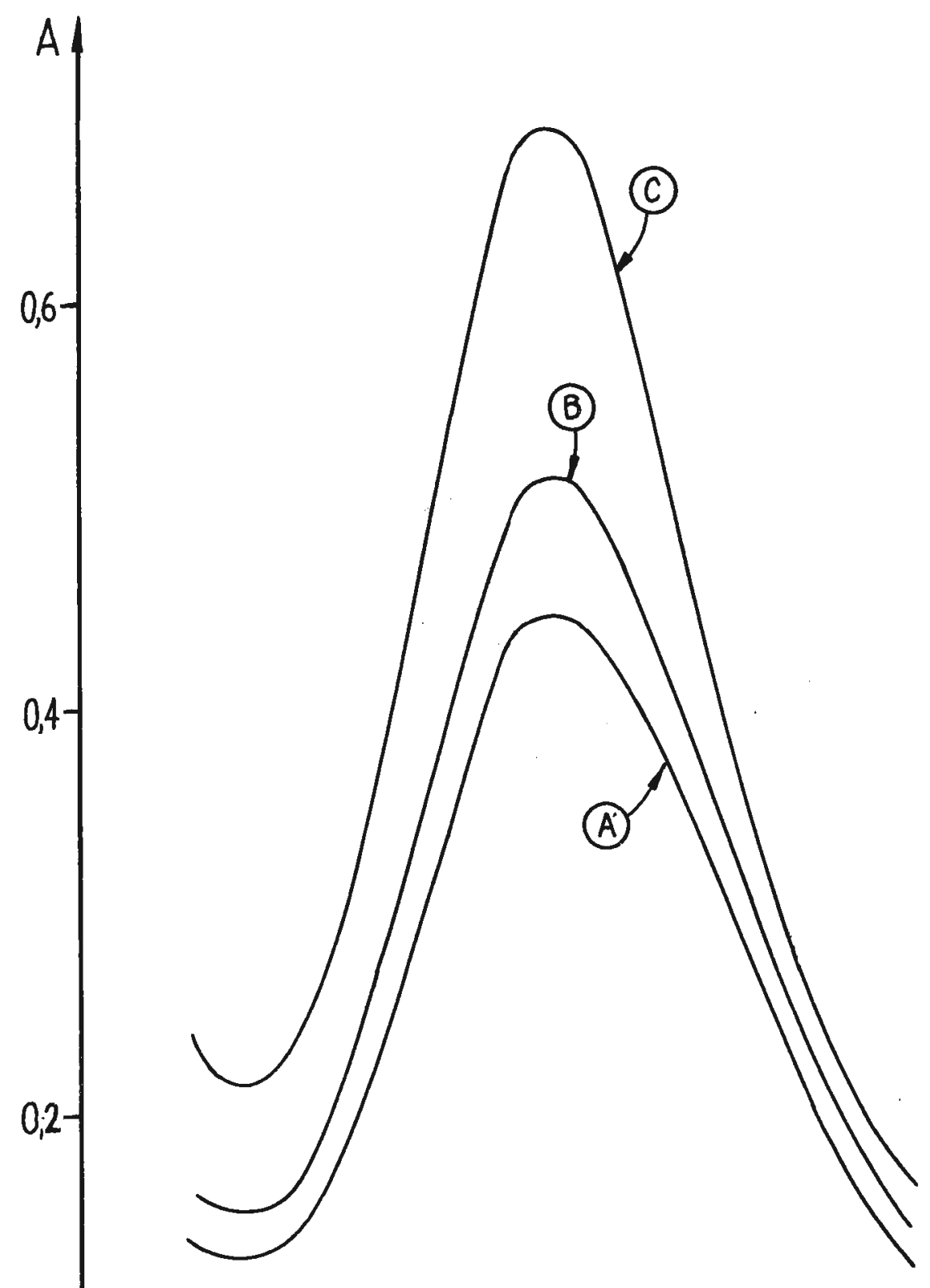

(D)

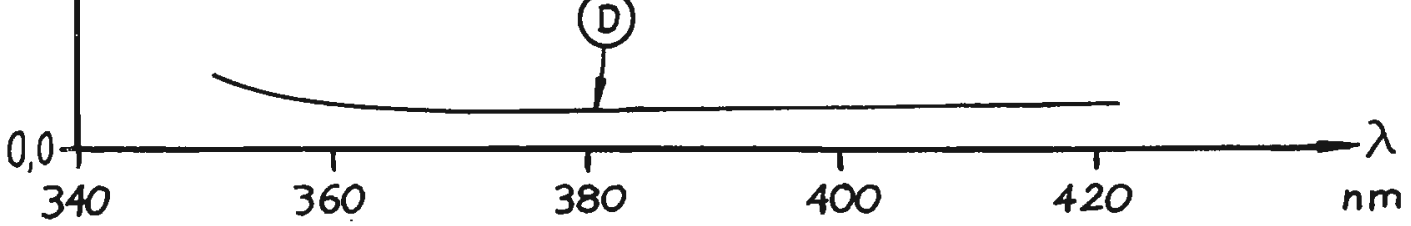

GRÁFICO III

Espectros das Especies Extraídas de Soluções Aquosas Contendo Platina (IV) e Iodeto

Curva A - Pt: $0,24 \times 10^{-6}$ moles; I : $0,68 \times 10^{-6}$ moles Curva B - Pt: $0,70 \times 10^{-6}$ moles; I : $0,33 \times 10^{-6}$ moles Curva C - $\mathrm{PtI}_{2}\left(\mathrm{Ph}_{3} \mathrm{Sb}\right)_{2}$ - segundo LEVI

Curva D - $\mathrm{Ph}_{3} \mathrm{Sb}$ em benzeno 
Nota-se também que na região do máximo de absorção dos extratos obtidos, a solução benzênica de trifenilestibina tem absorbân cia desprezível, o que torna possível o uso do benzeno puro como branco.

\section{Compostos Extraídos a partir de Platina (II)}

Cloreto de platina (II) foi utilizado como reagente para iodeto em substituição ao ácido cloro-platínico usado normalmente.

Conforme se vê na figura III o iodeto extrai: dando solu ção orgânica idêntica à obtida a partir de platina (IV), mas nesse caso, a partir de solução que contenha cloreto e/ou brometo, também são obtidos extratos coloridos que, embora não apresentem grande absorbtividade no ponto onde o iodo-complexo tem seu máximo de absorção, constituem in terferência. Com platina (IV), frisamos, isto não acontece.

\section{Influência da Concentração de Trifenilestibina na fa- se orgânica}

Efetuaram-se algumas extrações com quantidades decrescen tes de reagente na fase orgânica. Verifica-se que em concentrações acima de $0,5 \%$ (massa/volume) os resultados são concordantes. Em menores con centrações, para as quantidades de iodeto estudadas, as extrações são demoradas e não quantitativas. (Ver tabela 32)

\section{TABELA $\quad 32$}

INFLUENNCIA DA CONCENTRAÇÃO DE Ph ${ }_{3}$ Sb NA FASE ORGÂNICA

\begin{tabular}{|c|cc|}
\hline \multicolumn{3}{|c|}{ Valores de Absorbância obtidos (385 nm) } \\
$(35,6 \mu \mathrm{g})$ & \multicolumn{2}{c|}{$\mathrm{A}_{38}$} \\
\hline$\% \mathrm{Ph}_{3} \mathrm{Sb}$ & 0,232 & 0,240 \\
$1 \%$ & 0,233 & 0,247 \\
$0,5 \%$ & 0,190 & 0,184 \\
$0,3 \%$ & & \\
\hline
\end{tabular}




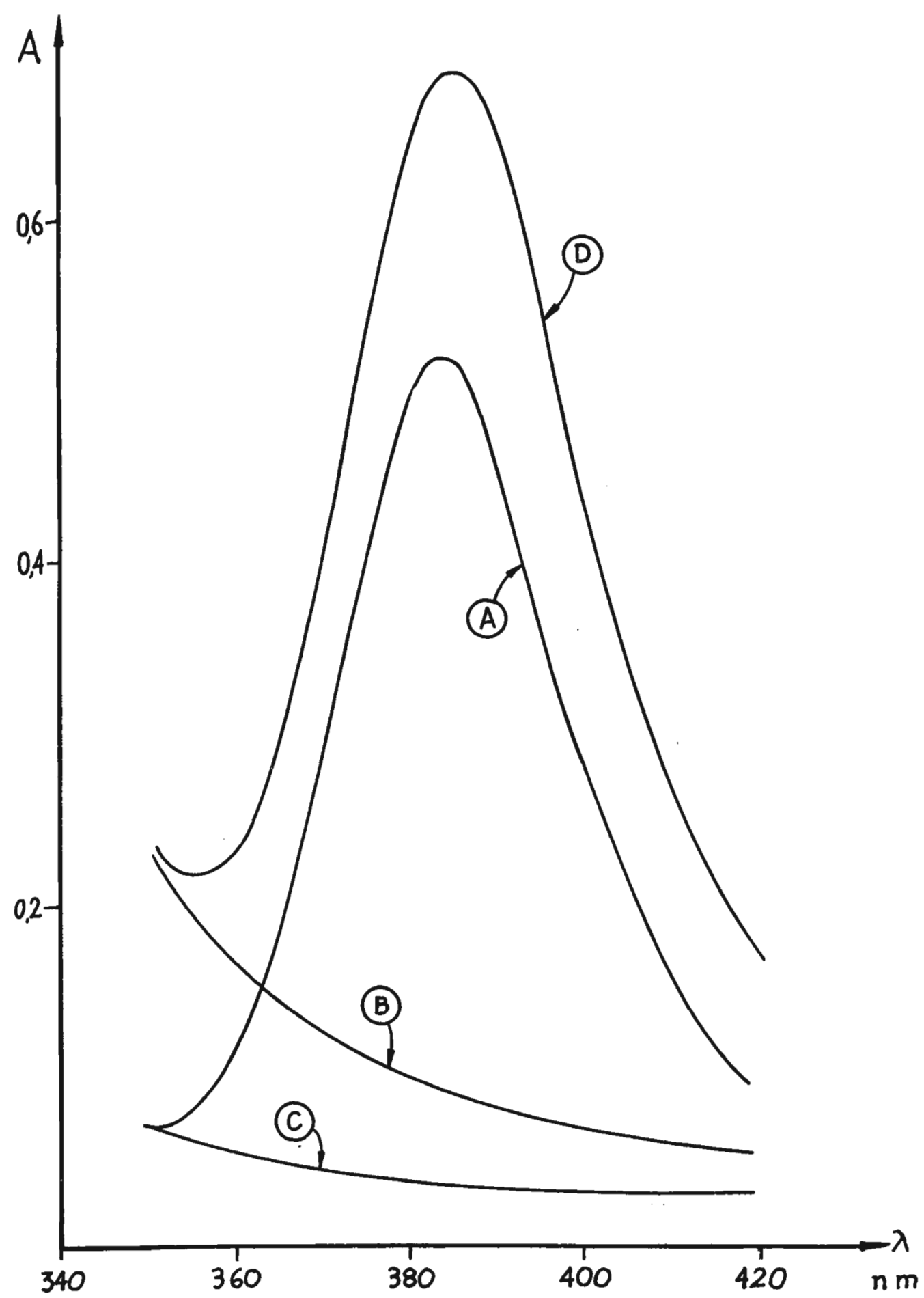

GRAFICO III

Lspécies Extraìdas a partir de Soluçao Aquosa de Pt (II) Curva A: I Curva B: Br Curva C: Cl Curva D: $\quad \mathrm{PtI}_{2}\left(\mathrm{Ph}_{3} \mathrm{Sb}\right)_{2}$ segundo LEVI 


\section{Influência da Acidez da fase aquosa}

Normalmente o reagente responsável pela acidez da fase a quosa é a platina, visto que sua solução é preparada em HCl O,I N. Efe e tuou-se uma série de medidas onde se adicionaram quantidades variáveis de HCl $0,1 \mathrm{~N}$. Não há variação apreciável nos resultados obtidos como mos tra a tabela 33 .

\section{TABELA 33}

INFLUENCIA DA ACIDEZ DA FASE AQUOSA

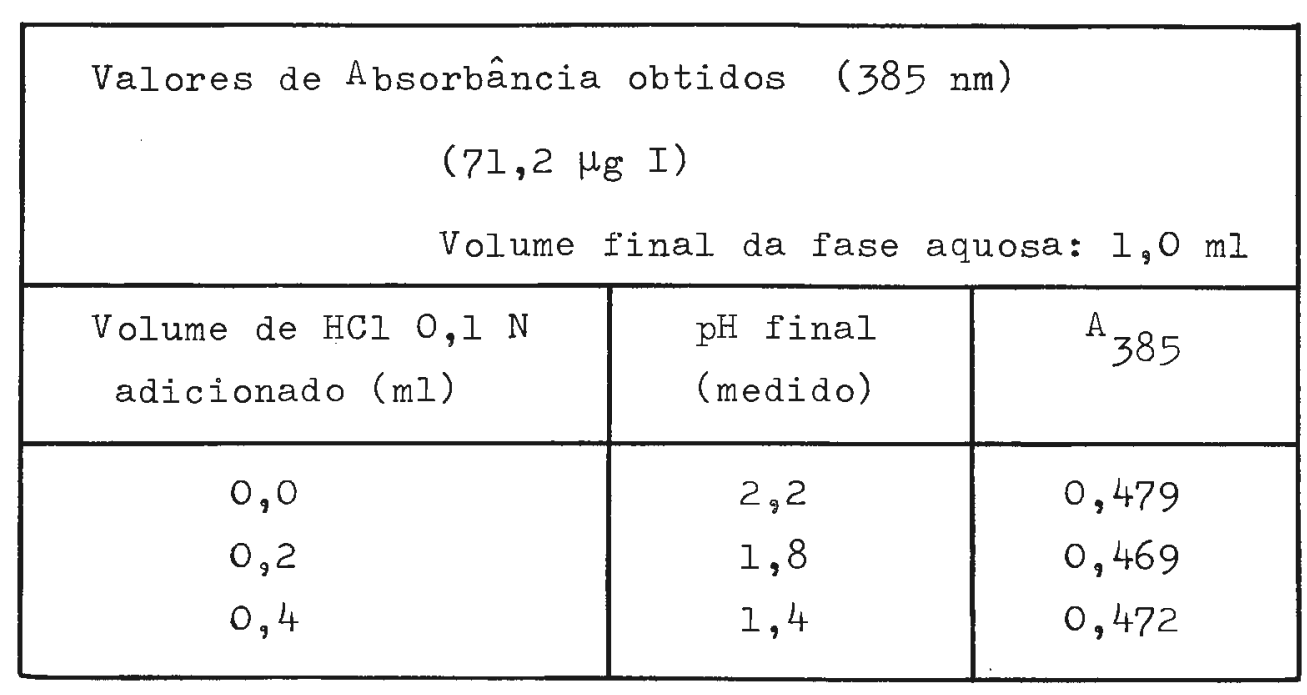

Deve-se ressalvar porém que em meio fortemente ácido a reprodutibilidade das medidas é muito dificil, certamente devido à faci lidade com que o iodeto se oxida ao ar nestas condições.

\section{Influência da Concentração de Platina}

Efetuou-se uma série de extrações de iodeto na presença de quantidades crescentes de platina para mostrar a independência dos resultados desta variável. Os dados obtidos estão na tabela 34. 
TABELA 34

INFLUENACIA DA CONCENTRAÇÃO DE PLATINA

\begin{tabular}{|c|c|}
\hline \multicolumn{2}{|c|}{$\begin{aligned} \text { Valores de Absorbância obtidos (385 nm) } \\
(35,6 \mu \mathrm{g} \mathrm{I})\end{aligned}$} \\
\hline Pt presente $(\mu g)$ & $\mathrm{A}_{385}$ \\
\hline 300 & 0,234 \\
\hline 1400 & 0,228 \\
\hline 5000 & 0,233 \\
\hline
\end{tabular}

Foi verificado também não haver desvio da lei de Lambert -Beer para o iodeto, desde que seja mantido um excesso de platina so bre êstes íons.

\section{Influência do Tempo de Equilíbrio entre as fases}

A partir de várias fases aquosas com as mesmas concentra cões de iodeto obtiveram-se vários extratos orgânicos cuja única diferença foi o tempo de equilibrio entre as duas fases, mantidas ao abrigo da luz direta.

Os valores de absorbância obtidos (veja tabela 35) mostram a necessidade de cerca de 2 horas de equilibrio para que a absorbância do extrato orgânico atinja um valor constante.

\section{TABELA 35}

INFLUENCIA DO TEMPO DE AGITAÇÃO

\begin{tabular}{|c|c|}
\hline \multicolumn{2}{|c|}{ Valores de Absorbância obtidos (385 nm) } \\
$(71,2 \mu \mathrm{g} I)$ \\
\hline tempo de equilíbrio entre \\
as fases (minutos) & ${ }^{\mathrm{A}} 385$ \\
\hline 15 & 0,230 \\
41 & 0,315 \\
71 & 0,372 \\
329 & 0,472 \\
& 0,458 \\
\hline
\end{tabular}




\section{Eficiência da Extração}

Mesmas quantidades de iodeto foram sucessivamente extraí das com 1, 2 e 3 porções de fase orgânica contendo trifenilestibina. Os resultados obtidos em todos os casos foram concordantes. Conclui-se que uma extração apenas é suficiente para tirar todo o iodeto da fase aquosa, ou seja, a porcentagem de extração é praticamente 100\%.

Deve-se lembrar que o longo periodo de equilíbrio a que se submetem as fases antes de separar a fase orgânica, certamente é o responsável pelo carácter quantitativo de apenas uma extração.

Verificou-se também que a diluição da fase aquosa inicial ao dobro ou ao triplo de seu volume original, não causa alteração mensu ráveis na absorbância do extrato orgânico obtido.

\section{Curva Padrão. Faixa de Trabalho e Precisão, Interferências}

\section{Verificação da Lei de Lambert-Beer}

A proporcionalidade entre concentrações de iodeto na fase aquosa inicial e absorbâncias do extrato orgânico obtido é verificada conforme mostra a figura IV.

\section{Gráfico de Ringbom}

A construção de um gráfico segundo as recomendações de Ringbom (84) indica que a faixa ideal para o trabalho é aquela que corresponde à concentração de iodeto na fase aquosa inicial entre aproxima damente 35 e $120 \mathrm{ppm}$. (Ver figura V).

\section{Precisão das Medidas}

Para avaliar a reprodutibilidade das medidas dentro da faixa de maior precisão, segundo o gráfico de Ringbom, foram efetuados alguns conjuntos de medidas em várias concentrações de iodeto segundo indica a tabela 36 . 


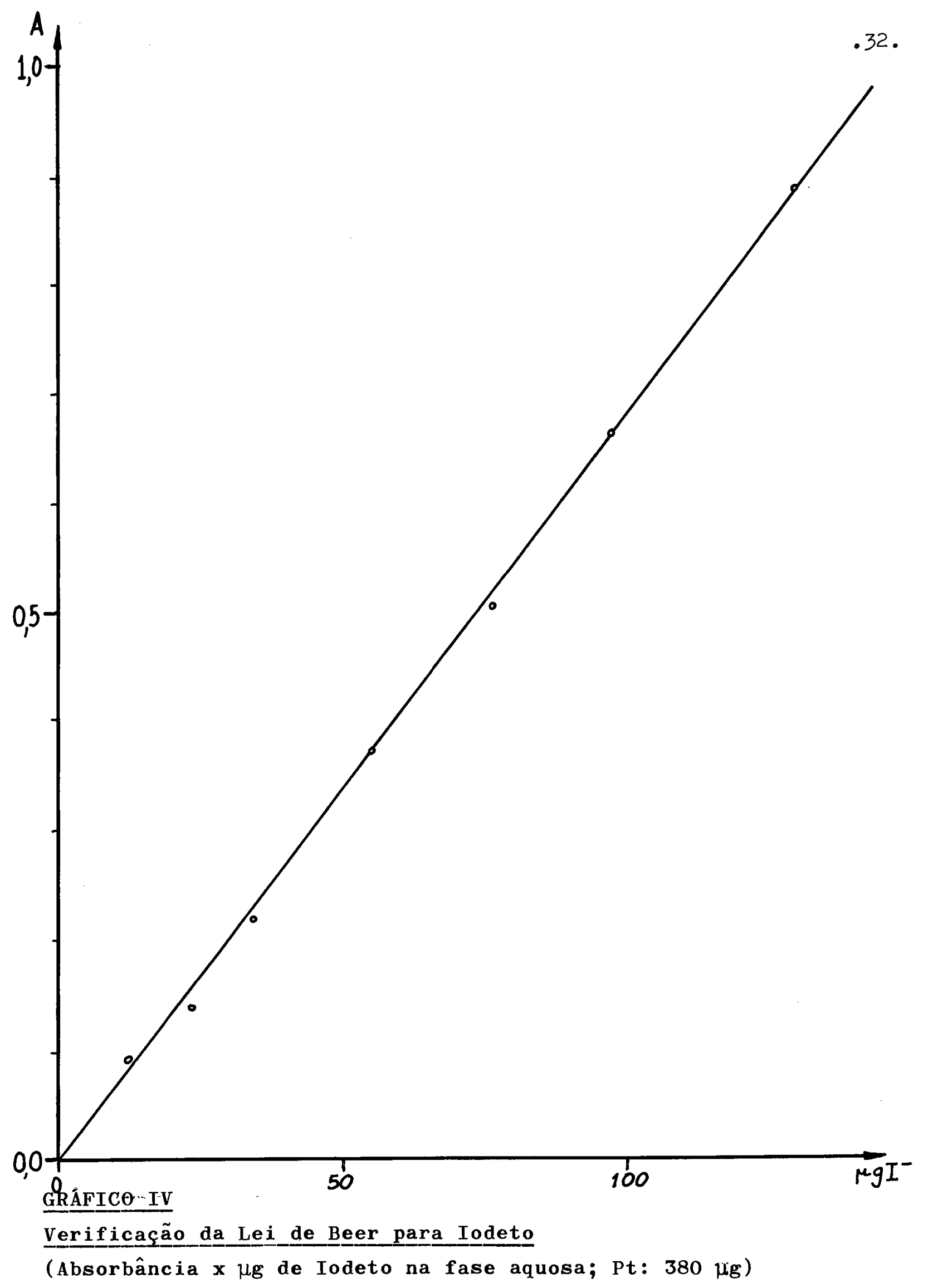


.33.

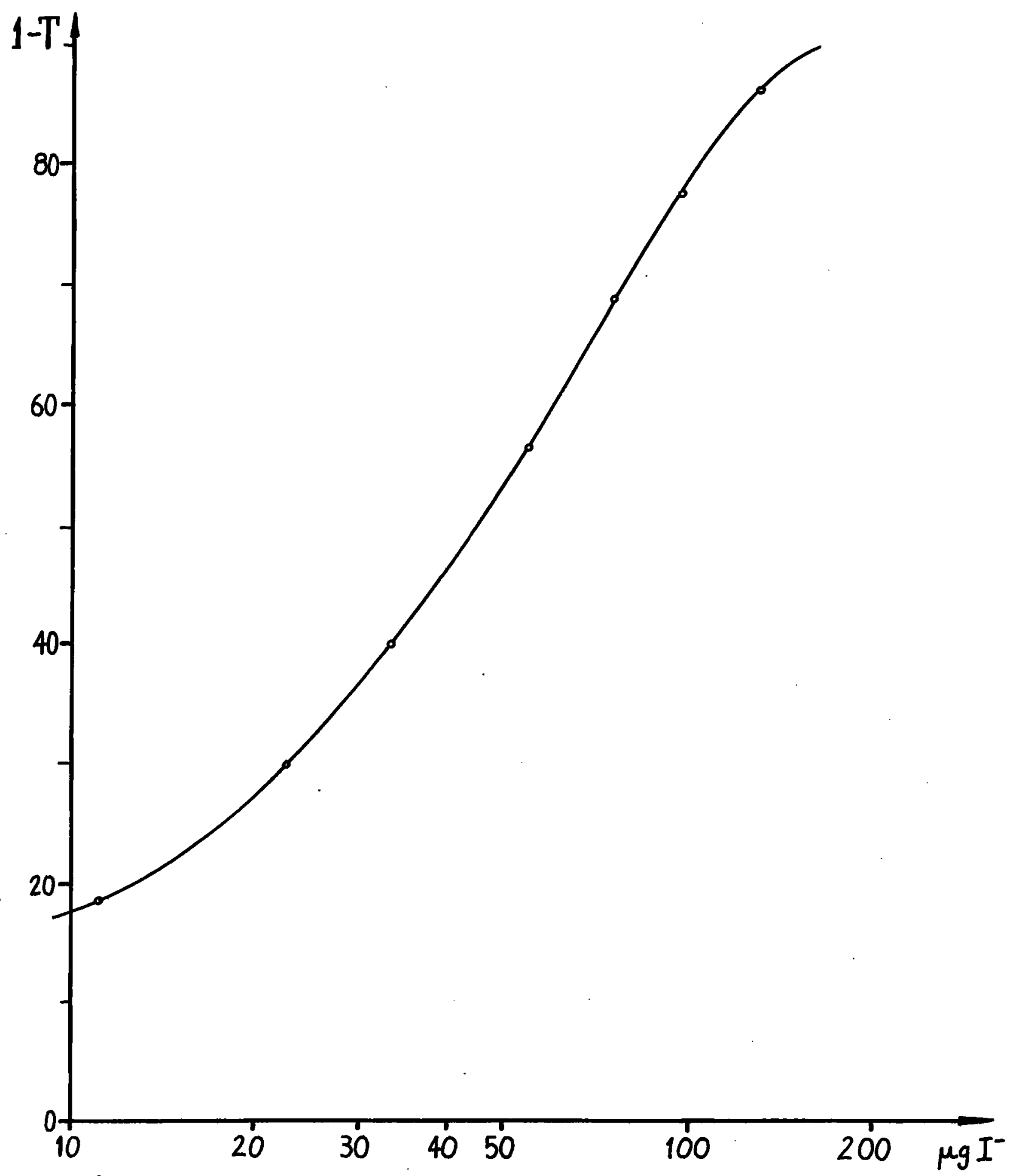

GRÁFICO V

Diagrama de Ringbom para Iodeto 
TABELA 36

PRECISAO DAS DETERMINAÇOES DE IODETO

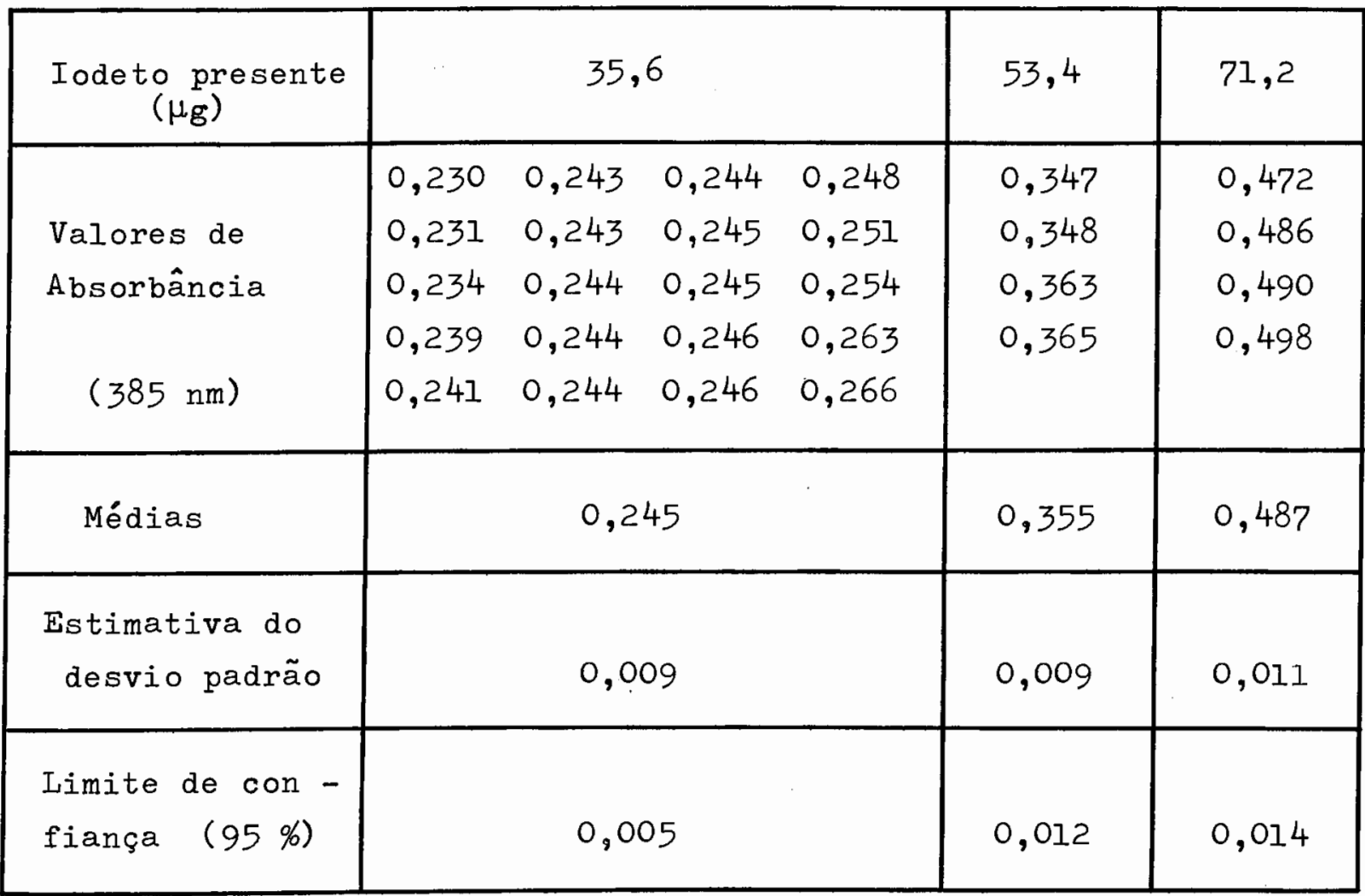

Expressos em concentrações de iodeto temos os seguintes valores $(36,3 \pm 0,8) \mu_{g},(52,7 \pm 1,8) \mu_{g} e(72,2 \pm 2,1) \mu_{g}$ para os in tervalos de confiança para $95 \%$ das medidas.

\section{Determinações de Iodeto na Presença de Ions estranhos}

o procedimento para determinar iodeto foi efetuado em so luções que continham iodeto na presença de vários fons estranhos. tabela 37 indica as porcentagens de iodeto recuperadas nos diversos casos.

Constituem sérias interferências, azoteto, cianeto e altos teores de tiocianato que devem impedir a extração por complexarem forte e completamente a platina. Teores módicos de tiocianato são ex traídos junto com o iodeto. Outros íons estudados, inclusive cloreto e brometo, mesmo em altas concentrações, não interferem. 
TABELA 37

DETERMINAÇAO DE IODETO NA PRESENÇA DE IONS ESTRANHOS

\begin{tabular}{|c|c|c|}
\hline \multicolumn{3}{|c|}{$\begin{array}{l}\text { Porcentagens de iodeto recuperado } \\
\qquad\left(35,6 \mu_{\mathrm{g}} \mathrm{I}\right)\end{array}$} \\
\hline Ion estranho presente & $\mu_{g}$ & $\%$ I recuperado \\
\hline $\mathrm{N}_{3}^{-}$ & $10^{3}$ & 0 \\
\hline $\mathrm{CN}^{-}$ & $10^{3}$ & 0 \\
\hline $\mathrm{SCN}^{-}$ & $10^{3}$ & 230 \\
\hline $\mathrm{SCN}^{-}$ & $10^{4}$ & 5 \\
\hline $\mathrm{SO}_{4}^{2-}$ & $10^{3}$ & 100 \\
\hline $\mathrm{NO}_{3}^{-}$ & $10^{3}$ & 99 \\
\hline $\mathrm{Cl}^{-*}$ & $10^{4}$ & 100 \\
\hline $\mathrm{Br}^{-}$ & $10^{3}$ & 100 \\
\hline $\mathrm{Br}^{-}$ & $10^{4}$ & 102 \\
\hline $\mathrm{HPO}_{4}^{2-}$ & $10^{3}$ & 101 \\
\hline $\mathrm{Ac}^{-}$ & $10^{3}$ & 98 \\
\hline
\end{tabular}

\section{Execução do Método}

\section{Procedimento}

Em um tubo de ensaio, provido de tampa esmerilhada, com cerca de $10 \mathrm{ml}$, pipeta-se $0,1 \mathrm{ml}$ de ácido cloroplatínico e $1 \mathrm{ml}$ de solu ção benzênica de trifenilestibina. Adiciona-se então $1,00 \mathrm{ml}$ da amostra que deve conter. $30-120 \mu_{g}$ de iodeto, neutra ou ligeiramente ácida.

Agita-se mecânicamente por 2 horas, findas as quais centrifuga-se para a separação das fases. Ai fase orgânica é transferida com 
uma pipeta de extração (92) para um balão de $5 \mathrm{ml}$ cujo volume é completado com pequenas porções de benzeno, utilizado previamente para a lava gem da fase aquosa que restou no tubo onde foi efetuada a extração.

Lê-se a absorbância desta solução benzênica em $385 \mathrm{~nm}$ em cubas de $1,00 \mathrm{~cm}$ de espessura, contra branco efetuado em paralelo onde a solução problema é substituída por água destilada.

Os pontos da curva padrão são identicamente obtidos.

O trabalho deve ser efetuado a temperaturas entre 20 e $25 \stackrel{\text { OCC. }}{2}$

\section{Aplicação}

Para testar a aplicabilidade do método analítico elabora do foi analisado o teor de iodeto de uma amostra de cloreto de sódio, que se dizia conter não mais de $1 \%$ de iodo. Uma massa exatamente conhe cida da amostra (pouco mais de $1 \mathrm{~g}$ ) foi dissolvida em água e diluída a $100,0 \mathrm{ml}$. Daí se retiraram alíquotas de $0,5 \mathrm{ml}$ para análise. Nas duas a líquotas analisadas foram encontrados os valores de $0,75 \%$ e $0,78 \%$ de io deto.

\section{E. Detalhes Experimentais}

Nesta secção são incluidos detalhes experimentais comple mentares, omitidos anteriormente por não impedirem a compreensão das ex periências realizadas.

\section{Espectros e Medidas Espectrofotométricas}

Os espectros foram obtidos em espectrofotômetros Beckmann modelo DBG e Cary modelo 14 munidos de registradores.

Para as determinações quantitativas as medidas espectrofotométricas foram feitas em um aparelho Zeiss modelo PMQ-10. 


\section{Preparação de cloreto de platina (II)}

Aplicou-se o método descrito por COOLEY e BUSCH (93) de redução do ácido cloro-platínico por hidrazina. Partiu - se de 18 de $\mathrm{H}_{2} \mathrm{PtCl}_{6} \cdot 6 \mathrm{H}_{2} \mathrm{O}$ e obteve-se $0,37 \mathrm{~g}$ de $\mathrm{PtCl}_{2}$ que foi levado a volume de $5 \mathrm{ml}$ com $\mathrm{HCl} \mathrm{O}, 1 \mathrm{~N}$ e utilizado conforme descrito anteriormente.

\section{Soluções e Reagentes}

(a) Acido Cloro-platínico. I g de $\mathrm{H}_{2} \mathrm{PtCl}_{6} \cdot 6 \mathrm{H}_{2} \mathrm{O}$ é dissolvido e levado a $100 \mathrm{ml}$ com $\mathrm{HCl} 0,1 \mathrm{~N}$, dando soluções com $1,9 \times 10^{2} \mu \mathrm{g}$ de Pt/gota.

(b) Trifenilestibina. O reagente de boa qualidade ( Ko dak) foi usado diretamente.

(c) Benzeno seco sobre $\mathrm{CaCl}_{2}$ e destilado. Se necessário, tratado previamente com $\mathrm{H}_{2} \mathrm{SO}_{4}$ conc. e lavado com água.

(d) Solução de Iodeto de Sódio o sal P.A. é seco a 120 oC. Prepara-se então solução 0,1 M $(630 \mu g$ de I/gota) e padroniza -se gravimetricamente com prata (94). Desta solução preparam-se, por dilui ção, as soluções utilizadas.

(e) Outros sais (interferentes). Sais de padrão P. A. São pesados e diluídos com água a volumes apropriados.

\section{Atgitação Mecânica}

Os tubos fechados são colocados em um suporte apropria do, que se prende a plataforma de um agitador mecanico Sargent, modelo $s-74050$.

\section{F. Considerações Gerais}

Embora a literatura apresente uma farta quantidade de mé todos eletroanalíticos sensíveis e seletivos para a determinação de io deto, os métodos mais tradicionais não têm sido completamente superados. 
Trabalhos recentes, como por exemplo o de SCHNEPFE (85) ainda utilizam a formação de iodo e sua determinação colorimétrica com amido. Isso vem justificar o aparecimento de outros métodos, entre os quais destacam-se por sua extrema sensibilidade, as recentes determinações de iodeto ba seadas em efeitos catalíticos (86-87).

o método apresentado neste capítulo baseia-se no fato do iodeto formar com a platina um complexo extraível em condições em que outros halogênios não reagem. Essa seletividade possivelmente depende do maior carácter redutor do iodeto em relação aos outros halogênios, visto que o reagente utilizado contém Pt(IV) e o produto obtido Pt(II). o papel desempenhado pelo iodeto em reduções de complexos de platina(IV, tem sido destacado por alguns autores (88-89).

Embora apresente algumas sérias interferências de outros ions, cremos que o método é comparável a outros apresentados recentemen te (90-91) que também fazem a extração em solventes de iodo-complexos e do mesmo modo apresentam problemas de interferências, ficando um deles (90) muito a desejar com respeito à eficiência da extração.

Sob outro aspecto, acreditamos que o nosso método mostra a possibilidade de novas utilizações analíticas para complexos que vi nham sendo utilizados somente para a determinação de cátions. 


\section{COLETA E DOSAGEM DE MONÓXIDO DE CARBONO}

\section{A. Reação}

A reação entre azido-complexos e monóxido de carbono con duzindo aos isocianato-complexos correspondentes parece ter sido descoberta independentemente pelos grupos de BECK (95-97) e COLLMANN (98).

Nos estudos realizados por esses autores é interessante notar que o azoteto livre não reage com o monóxido de carbono, sendo o isocianato produzido apenas se o grupo $-\mathrm{N}_{3}$ estiver ligado a determinados metais ou certos grupos orgânicos.

Dentre os complexos que reagem está o $\mathrm{Pd}\left(\mathrm{N}_{3}\right)_{2}\left(\mathrm{Ph}_{3} \mathrm{P}\right)_{2}$ cujas condições de formação e extração em solventes já são apontadas por SENISE e LEVI (48.5I).

O fato de soluções benzênicas deste complexo reagirem fa cilmente com monóxido de carbono contido em misturas gasosas, conduzindo ao isocianato complexo correspondente e libertando nitrogênio segundo a equação:

$$
\mathrm{Pd}\left(\mathrm{N}_{3}\right)_{2}\left(\mathrm{Ph}_{3} \mathrm{P}\right)_{2}+2 \mathrm{CO}-\mathrm{Pd}(\mathrm{NCO})_{2}\left(\mathrm{Ph}_{3} \mathrm{P}\right)_{2}+2 \mathrm{~N}_{2}
$$

lẹvou a elaboração de método para a coleta e dosagem espectrofotométrica de co baseado na diferença das características espectrais na re gião do ultravioleta próxima do visivel, que o azido- e o isocianato-com plexo apresentam.

Testes preliminares indicaram que os correspondentes com plexos com arsina e estibina também reagem com Co. Porém devido às di ficuldades do preparo e caracterização de tais complexos não se conse guiu utilizá-los.

\section{B. Características dos Compostos}

A preparação do composto $\mathrm{Pd}\left(\mathrm{N}_{3}\right)_{2}\left(\mathrm{Ph}_{3} \mathrm{P}\right)_{2}$ como indicada 
por BECK (99-100) ou efetuada da maneira correspondente a que LEVI (48) indica para o iodo-complexo $\mathrm{PdI}_{2}\left(\mathrm{Ph}_{3} \mathrm{Sb}\right)_{2}$, não conduziram a rendimen tos elevados.

Possivelmente isto é devido ao fato de que em ambos os casos partiu-se do complexo tetraazido-paladato (II) na presença de excesso de azoteto livre - no primeiro caso em meio aquoso-etanólico e no segundo em um sistema bifásico água-benzeno - e este excesso de azoteto dificulta a entrada de dois ligantes trifenilfosfina em duas posições de coordenação do paládio. Dificuldades do mesmo tipo, mas em maior grau, foram aliás encontradas por ALONSO e PITOMBO (101) ao tentarem a preparação do complexo correspondente contendo trĭfenilarsina, certamente de vido ao menor poder complexante da arsina.

Depois do relativo fracasso destas preparações, conse guiu-se bom rendimento partindo de $\mathrm{PdCl}_{2}\left(\mathrm{Ph}_{3} \mathrm{P}\right)_{2}$ preparado segundo as recomendações de LEVI (48). A solução benzênica deste complexo é equilí brada com fase aquosa contendo adequada concentração de azoteto: a fase orgånica passa de amarela a alaranjada e na fase aquosa se consegue iden tificar íns cloreto, originalmente ausentes, indicando assim a troca de cloreto por azoteto com formação do azido-complexo na fase orgânica. Esta é separada e por evaporação lenta ou cristalização por adição de éter é obtido o composto $\mathrm{Pd}_{3}\left(\mathrm{~N}_{3}\right)_{2}\left(\mathrm{Ph}_{3} \mathrm{P}\right)_{2}$.

Conforme o tratamento a que seja submetida a solução ben zênica obtem-se Lormas diferentes de produto:

(a) a lenta evaporação desta solução benzênica conduz a sólido amarelo bem cristalizado que dissolvido em benzeno apresenta um espectro com apenas um máximo no UV próximo, em cerca de $345 \mathrm{~nm}$.

(b) o sólido que se cristaliza pela adição de éter à solução benzênica, apresenta matiz alaranjado e dissolvido em benzeno apresenta espectro com dois máximos de absorção na região do UV próximo, em comprimentos de onda de aproximadamente 305 e $345 \mathrm{~nm}$, sendo que em $345 \mathrm{~nm}$ a absortividade é levemente maior que em $305 \mathrm{~nm}$.

Este produto se dissolve parcialmente em hexano e esta solução na região do UV próximo apresenta apenas um máximo de absorção em $345 \mathrm{~nm}$ aproximadamente. A parte não dissolvida em hexano, dissolve se totalmente em benzeno e a solução assim obtida apresenta máximos de 
absorção nas regiões de $345 \mathrm{~nm}$ e $305 \mathrm{~nm}$; neste caso o máximo situado em $345 \mathrm{~nm}$ tem absortividade bem diminuída com relação ao de $305 \mathrm{~nm}$.

Estes fatos nos indicam que o complexo deve apresentar duas formas - possivelmente isômeros cis e trans, muito comuns neste tị po de compostos - das quais uma se conseguiu obter pura, como indicado acima em (a), e a outra não. Diferenças marcantes apresentam estas formas quanto as suas solubilidades em hexano e quanto aos seus espectros na região da ultravioleta próxima do visível.

Cumpre observar que a própria solução benzênica do sólido amarelo, supostamente uma forma pura, com apenas o máximo de absor ção em $345 \mathrm{~nm}$ na região do UV próximo, se deixada por cerca de 10 dias à luz difusa, apresenta um pequeno máximo de absorção ao redor de 305 $\mathrm{nm}$, o que indica o aparecimento da outra forma.

Tanto o produto de máximo único, como o de dois máximos de absorção no UV próximo têm seus espectros alterados após a passagem de excesso de monóxido de carbono através de suas soluções benzênicas. o produto formado apresenta um máximo de absorção em $335 \mathrm{~nm}$, aproximada mente, com absortividade cerca de duas vezes maior que a do azido com plexo em $345 \mathrm{~nm}$ e corresponde ao isocianato-complexo preparado e caracterizado por SINHA e NORBURY (102-103).

Devido a pouca quantidade obtida, a única característica verificada deste complexo foi seu espectro na região do ultravioleta.Só com este dado não se conseguiu verificar diferença alguma entre os produtos formados pela passagem de monóxido de carbono sôbre uma ou outra formas do azido-complexo indicadas anteriormente. Porém a partir de qual quer uma delas é possível a aplicação analítica proposta a seguir, ba seada na diferença entre os espectros que soluções do azido-complexo re agente e do isocianato-complexo formado após a reação com monóxido de carbono, apresentam na região do ultravioleta próximo.

\section{Medidas Espectrofotométricas no UV}

\section{Espectros diferenciais}

Conforme mostram as figuras VI e VII entre aproximadamen 


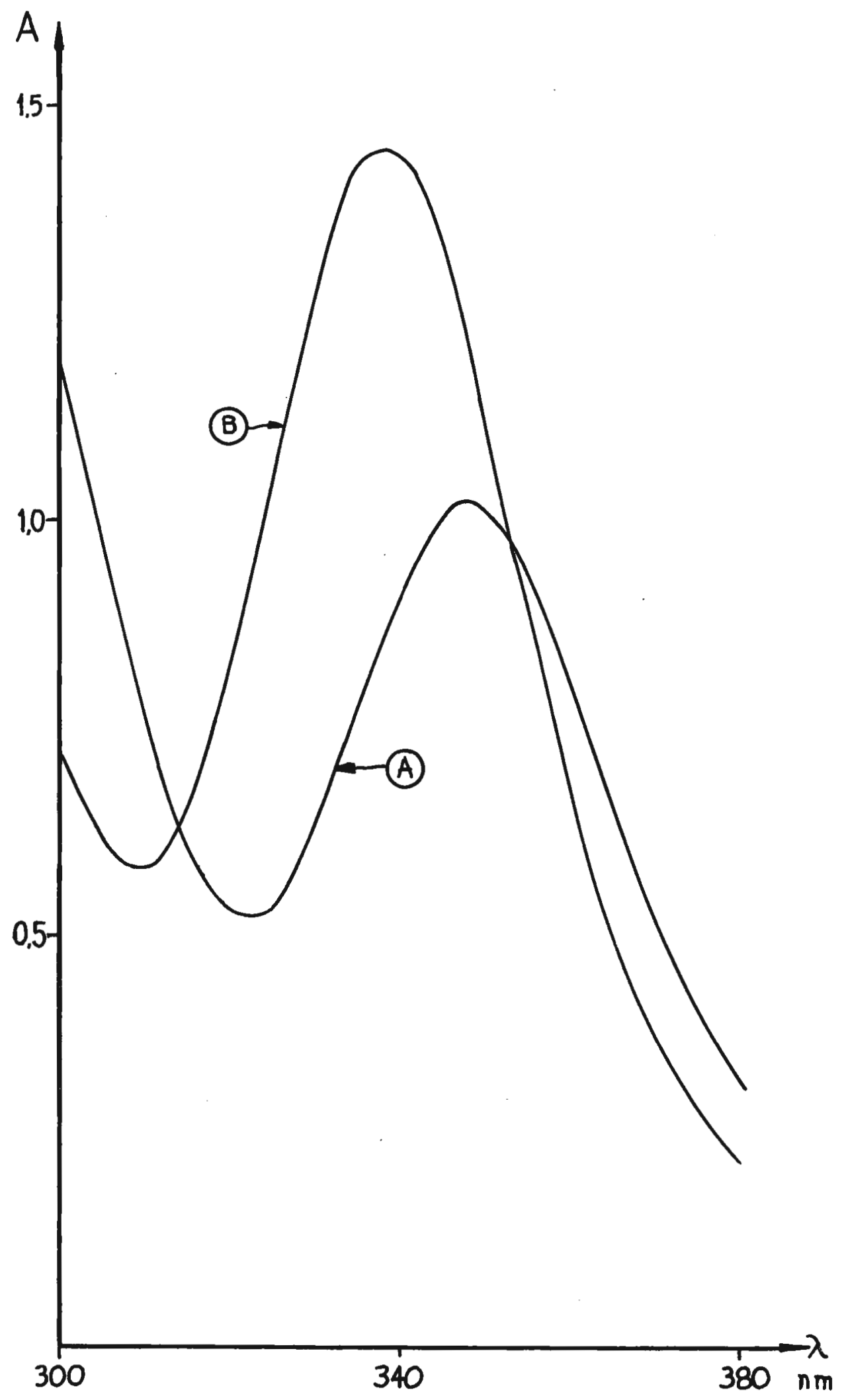

\section{GRÁFICO VI}

Espectros no UV próximo dos complexos reagente e produto Curva A: azido-complexo (preparação a ) Curva B: azido-complexo + CO 


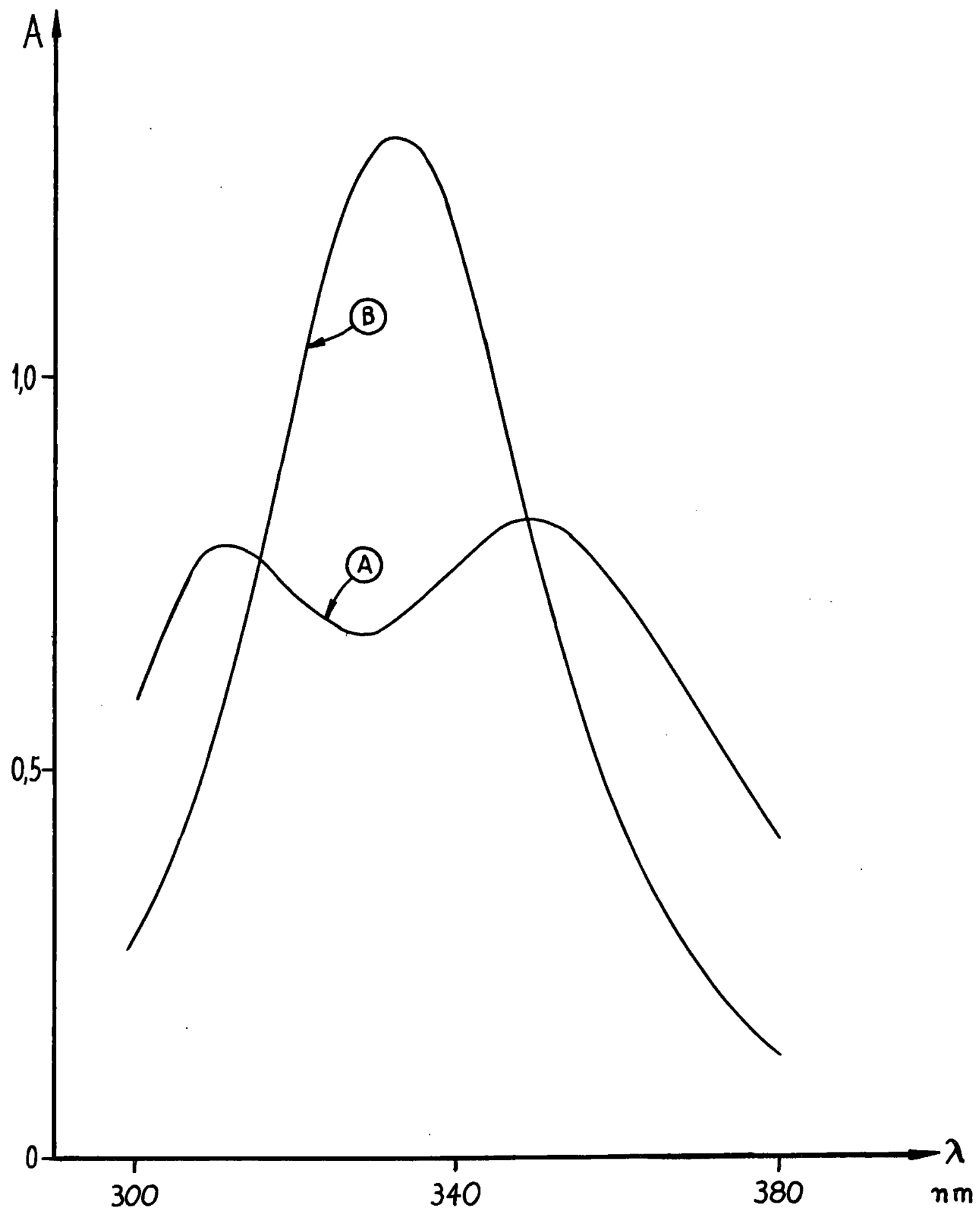

GRÁFICO VII

DSpectros no UV_próximo_dos_complexos reagente e produto Curva $A$ : azido-complexo (preparação b)

Curva B: azido-complexo $\because \mathrm{CO}$ 
te 315 e $350 \mathrm{~nm}$ o isocianato-complexo tem maior absortividade do que o azido-complexo. Nesta região a absorção da solução benzênica cresce com a absorção de monóxido de carbono. O ponto de maior diferença entre os espectros está em $333 \mathrm{~nm}$ que não coincide exatamente com o máximo de ab sorção do isocianato-complexo em $336 \mathrm{~nm}$.

A diferença entre as absorbências das soluções benzênicas do azoteto complexo original e da mistura formada após absorção de monó xido de carbono é proporcional à quantidade deste gás absorvido, sendo possível a construção de uma curva padrão.

Todavia, se a quantidade de CO que reage não o faz ape nas com uma pequena parcela do azido complexo presente, se deverá ter u ma curva padrão para cada concentração inicial do mesmo, visto que não poderão ser consideradas equivalentes as quantidades deste complexo que sobram sem reagir. Apesar deste inconveniente é vantajoso o uso deste procedimento pois, ao contrário, se for mantida elevada a concentração inicial de azido-complexo, a absorvância deste substrato será muito gran de e pequenas variações aí produzidas pela absorção de Co, darão medi das de baixa precisão.

\section{Curva Padrão}

A figura VIII mostra uma curva padrão típica efetuada pe la medida espectrofotométrica a $333 \mathrm{~nm}$ de soluções de azido-complexos que tenham estado em contacto com misturas gasosas contendo teores vari áveis de monóxido de carbono, contra uma solução idêntica mantida ao abrigo deste gás.

As quantidades de CO usadas nesta série são súficientes para reagir com quantidades que variam de aproximadamente 5 a $60 \%$ do azido-complexo presente.

\section{Precisão das Medidas}

Para avaliar a reprodutibilidade das medidas foram efetu adas 10 determinações a partir de uma mesma amostra de ar contendo Co. A tabela 41 mostra os valores obtidos e os parâmetros estatísticos calculados. 


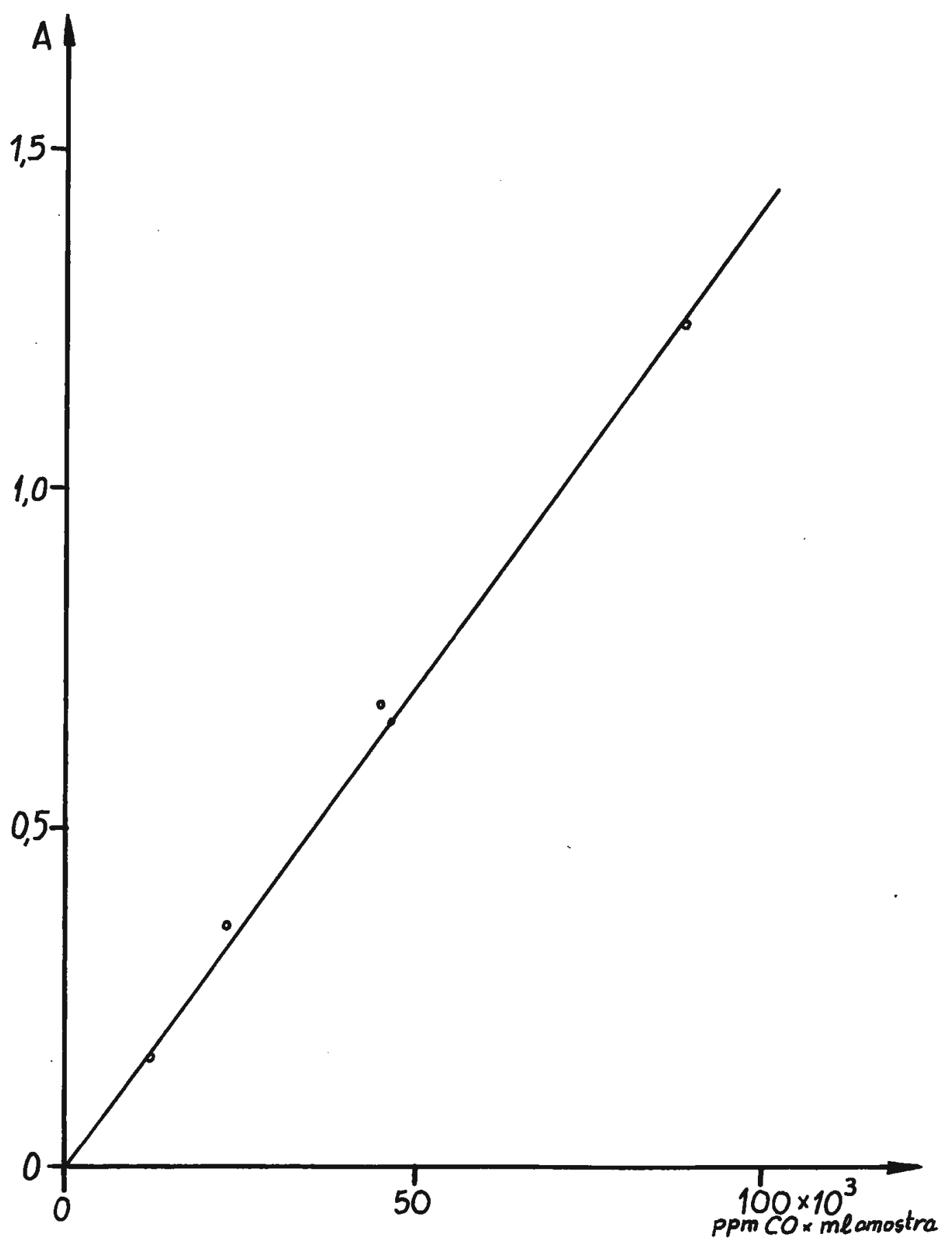

GRÁFICO VIII

Curva_Padrão para Determinaçãa a de Co

Procedimento: v. texto

Volume de amostra: $\sim 20 \mathrm{ml}$

Teor de C0: $700-3000$ ppm (A: 0,2 - 0,8) 
PRECISAO DAS DETERMINAÇOES ESPECTROFOTOMETRICAS DE CO

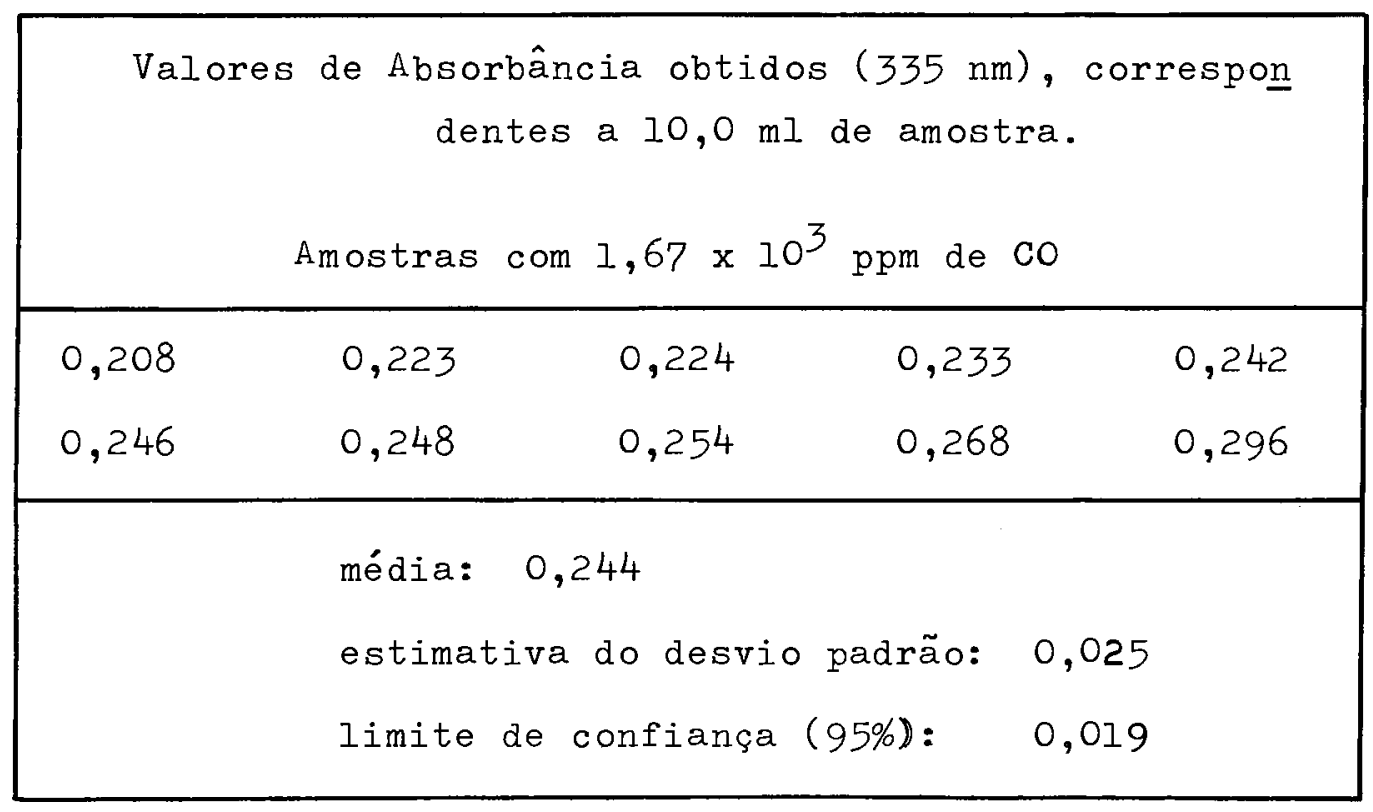

Em termos de concentração de CO a média e os limites de confiança para $95 \%$ das medidas são

$$
(1,76 \pm 0,14) \times 10^{3} \mathrm{ppm}
$$

\section{Procedimento}

(a) 5,00 ml de solução benzênica contendo $2,5 \mathrm{mg}$ do complexo $\mathrm{Pd}\left(\mathrm{N}_{3}\right)_{2}\left(\mathrm{Ph}_{3} \mathrm{P}\right)_{2}$ são colocadas em um balão de $25 \mathrm{ml}$ e levados a aparelhagem para coleta de CO (veja parte experimental);

(b) evacua-se a aparelhagem até que a solução benzênica comece a ferver;

(c) permite-se a entrada da mistura gasosa contendo CO, proveniente de uma bureta para gases. Mede-se o volume desta mistura (à pressão atmosférica) que entra para o balão. Agita-se por 40 minutos;

(d) retira-se o balão, dilui-se à marca com benzeno e me de-se a absorbância em $333 \mathrm{~nm}$, utilizando cubas de 1,00 cm de caminho ó tico, contra branco de apenas o complexo reagente, feito em paralelo; 
(e) se houver dificuldades em se conseguir volumes exata mente iguais das diversas misturas de monóxido de carbono, pode-se fa zer o gráfico padrão contendo nas abcissas "ppm $\mathrm{x} \mathrm{ml} \mathrm{de} \mathrm{CO"} \mathrm{e} \mathrm{nas} \mathrm{orde-}$ nadas as absorbâncias.

\section{E. Detalhes Experimentais}

\section{Aparelhagem. Padrões. Técnica de Coleta}

A preparação de misturas de ar com teor conhecido de monóxido de carbono para a padronização do método, seguiu técnica inspira da em DENNIS (104) e GUERIN (105) que apesar de primária conduziu a resultados satisfatórios. A figura IX mostra um esquema du aparelhagem utilizada.

o monóxido de carbono é produzido gotejando-se ácido fór mico sôbre ácido sulfúrico concentrado, aquecido em banho-maria à ebuli ção. O gás desprendido'é lavado em $\mathrm{NaOH}$ e recolhido sôbre água em um frasco que conta com um sifão que faz com que o gás permaneça à pressão atmosférica ou levemente superior, para evitar eventuais infiltrações de ar. Daí o CO é levado a uma bureta para gases onde são feitas as diluições convenientes com ar isento de CO.

Volumes determinados destas misturas de teores conheci dos de CO são postos em contacto com soluções benzênicas do reagente em aparelhagem previamente evacuada. Agita-se por determinado tempo para que haja a reação e depois dilui-se e leva-se ao espectrofotiometro para leitura e construção da curva padrão.

O tempo de contacto das soluções benzênicas com as misturas de CO deve ser de no mínimo 20 minutos para que as absorbâncias das soluções atinjam valores constantes. Para teores mínimos de co este tempo deve ser aumentado mas verificamos que com cerca de 30 minutos de agitação, em todos os casos já se atinge um valor constante de absorbân cia. Para dar uma margem de segurança estipulamos o tempo de agitação em 40 minutos. 


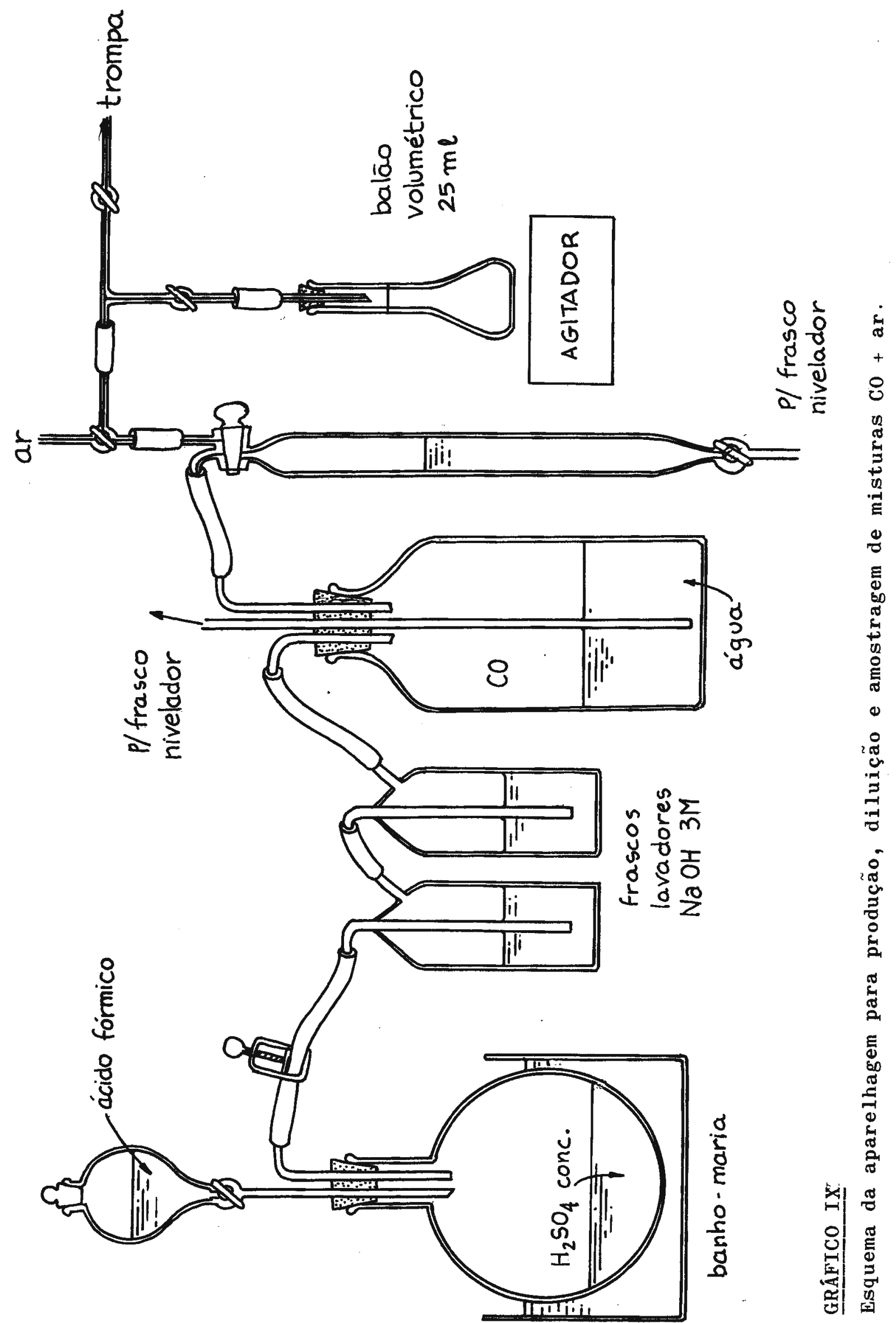




\section{Preparações}

(a) $\mathrm{PdCl}_{2}\left(\mathrm{Ph}_{3} \mathrm{P}_{2}\right.$, dicloro-bis(trifenilfosfina)-paládio (II) (Procedimento: modificação do indicado por LEVI (48) para o iodo -complexo). 0,35 (2 m moles) de $\mathrm{PdCl}_{2}$ são dissolvidos em $5 \mathrm{ml}$ de $\mathrm{HCl}$ conc. e levados a ebulição para eliminar o excesso do ácido. Dilui - se com água a $20 \mathrm{ml}$. Equilibra-se esta solução aquosa com $50 \mathrm{ml}$ de uma soIução benzênica contendo $1 \mathrm{~g}$ ( $4 \mathrm{~m}$ moles) de trifenilfosfina. A fase aquosa torna-se quase incolor e a fase orgânica toma coloração amarela, podendo aparecer um precipitado amarelo. Separa-se por decantação. A fa se benzênica contem o complexo que cristaliza pela lenta evaporação do solvente. (PF obtido 265-272 QC dec; PF esperado (46): 270 OC dec).

(b) ${\mathrm{Pd}\left(\mathrm{N}_{3}\right)}_{2} \frac{\mathrm{Ph}}{3}_{3} \mathrm{P}_{2}$, diazido-bis(trifenilfosfina)-paládio (II). $0,5 \mathrm{~g}$ do complexo preparado acima, dissolvido em benzeno é equilibrado com $20 \mathrm{ml}$ de água contendo $1 \mathrm{~g}$ (excesso) de $\mathrm{NaN}_{3}$. Agita-se intermitentemente por 1 hora. A fase orgânica passa da cor amarela para alaranjada. Separam-se as fases e evapora-se lentamente o benzeno. Obtem-se um sólido amarelo que depois de seco a vácuo funde a 1630-1650C com pouca decomposição. (o ponto de fusão deste complexo não está citado na literatura). o espectro na região do infravermelho mostra a banda forte em $2033 \mathrm{~cm}^{-1}$ que segundo BECK (99) deve ser atribuida ao azoteto.

Nota: Se à fase benzênica for adicionado éter, cristaliza um produto alaranjado de PF 1660-1680 C dec (Veja a secção de título Características dos Compostos).

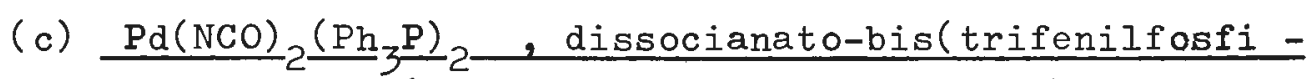
na)-paládio (II). A solução benzênica do azido-complexo preparado como acima é submetida a CO até que seu espectro no UV próximo não apresente mais alteração. Por evaporação obtem-se infima quantidade de sólido ama relado qué decompõe entre 2050 e 230 oC. O PF isocianato-complexo relatado (95) é 216 \&C dec.

\section{Medidas Espectrofotométricas}

Os espectros dos complexos reagentes e produto foram ob: tidos em um espectrofotômetro Beckmann Modelo DBG munido de registrador. As medidas para a construção de curva padrão e análises, foram obtidas em espectrofotômetro Zeiss Modelo PMQ-1O. 


\section{F. Considerações Gerais}

Embora se trate de importante problema analítico, a de terminação de monóxido de carbono por via espectrofotométrica, ao que parece, se baseia exclusivamente em medidas da absorção de soluções coloidais, formadas pela redução de sais de metais nobres (104-105). Embo ra não tenha impedido aplicações (106), a absortividade de tais colói des varia conforme fica bem esclarecido por CIUHANDU (107).

Embora exista indicação anterior (110), uma recente comu nicação de LAMBERT e HAMLIN (108) indica método que, segundo os autores, é o primeiro para determinar CO baseado na formação de um complexo colo rido solúvel. A série de reações por eles utilizadas não está bem escla recida. Também não são muito satisfatórias a proporcionalidade entre ab sorbância e concentrações de CO e a precisão das medidas. Esses fatores todavia não impediram que o método fosse aplicado posteriormente para determinar monóxido de carbono no sangue (109).

O reagente proposto neste capítulo possui algumas vantagens iniciais, tais como o caráter bem definido das espécies envolvidas. Conseguimos além disso uma melhor curva padrão e uma superior reproduti bilidade das medidas, o que mostra a potencialidade do método criado. Al gumas aplicações foram feitas analisando-se os gases de escapamento de automóveis, tendo sido encontrados resultados satisfatórios que só não puderam ser comparados com métodos baseados na redução de íons metáli cos a soluções coloidais dèido ao carácter dos mesmos.

BIBLIOTECA 
1. E relatado estudo sistemático da extratibilidade de complexos mistos de metais de transição com haletos, pseudohaletos e trifenilfosfina, arsina, estibina, sob condições variadas, com diversos solventes, mostrando as tendências gerais de comportamento das espécies envolvidas. Dessa ampla abordagem derivam algumas possibilidades de aplicações analíticas que são desenvolvidas.

2. A presença de cianeto impede a formação e destrói al guns complexos de paládio do tipo acima referido, fato que conduziu à elaboração de uma prova de toque para este ín. Papel convenientemente preparado, contendo complexo de paládio, é descorado por HCN desprendido de amostras contendo cianeto, possibilitando a identificação de 0,3 $\mu \mathrm{g}$ de $\mathrm{CN}$. Na presença de interferentes, algumas modificações de procedi mento tornam o teste praticamente específico.

3. A partir de soluções aquosas contendo o ácido hacloroplatínico (IV), soluções benzênicas de trifenilestibina somente extraem o produto organometálico na presença de iodeto e não de brometo ou cloreto. As condições para uma extração seletiva e subsequente determina ção espectrofotométrica de iodeto são indicadas, assim como as tolerâncias para outros íons estranhos. O método elaborado permite identificar iodeto na faixa de concentração de $6-24$ ppm na diluição final, sendo a medida espectrofotométrica efetuada em $385 \mathrm{~nm}$.

4. O complexo diazido-bis(trifenilfosfina)-paládio (II), em solução benzênica, reage com monóxido de carbono dando o isocianeto complexo correspondente, com mudança das características espectrais na região do ultravioleta próximo. Com base nesta reação, mostra-se que é possível a determinação espectrofotométrica de monóxido de carbono em misturas gasosas com teores $700-3000 \mathrm{ppm}$. 
1 - A. Cahours, H. Gal - Compt. Rend 70, 897 e 1380 (1870); 71, 208 (1870)

2 - M. Levi Malvano - Atti Accad. Lincei 17, 847 (1908); CA 4 , 3068 (1910)

3 - F.G.Mann, W.J.Pope - J. Chem. Soc. 124, 1754 (1922)

4 - G.T.Morgan, V.E.Yarsley - J. Chem. Soc. 127, 184 (1925)

5 - F.G.Mann, D. Purdie - J. Chem. Soc. 1549 (1935)

6 - F.G.Mann, A.F.Wells, D.Purdie - J. Chem. Soc. 1503 (1936)

7 - K.A.Jensen - Z. Anorg. Allgem. Chem. 229, 225 e 252 (1936); CA 31, 3753 e 1721 (1937)

8 - K.A.Jensen - Z.Anorg. Allgem. Chem. 222, 265 (1936); CA 31,1720 (1937)

9 - K.A.Jensen - Z. Anorg. Allgem. Chem. 229, 282 (1936); CA 31,1720 (1937)

10 - J. Chatt, F.G.Mann - J. Chem. Soc. 1622(1939)

11 - R.S.Nyholm, G.T.Sutton - J. Chem. Soc. 560(1958) e artigos seguintes

12 - R.J.H.6lark, J.Lewis, R,S.Nyholm, P.Pauling, G.B.Robertson -Nature 192, 222 (1961)

13 - J.Lewis, R.S.Nyholm, P.W.Smith - J. Chem.Soc.2592 (1962)

14 - J.Chatt, R.G.Welkins - J. Chem. Soc. 70(19'53) e referências

15 - J.Chatt, R.G.Welkins - J. Chem. Soc. 2532(1951)

16 - K.Issleib, G.Bohn - Z. Anorg. Allgem. Chem. 301, 188(1959)

17 - K.Issleib, G.DHIl - Z. Anorg. Allgem. Chem. 305, I (1960)

18 - L.M.Venanzi - J. Chem. Soc. 719 (1958)

19 - K.A.Jensen, B.Nygaard - Acta Chem. Scand. 3, 474(1949)

20 - F.A.Cotton, O.D.Fault, D.M.L.Goodgame, R.H.Holn - J.Am. Chem. Soc. 831780 e 4157(1961); Inorg. Chem. I, 239(1962)

21 - R.Colton, R.Levitius, G.Wilkinson - J. Chem. Soc. 4121(1960)

22 - T.A.Stephenson, G.Wilkinson - J. Inorg. Nucl. Chem. 28, 945(1966)

23 - W.T.Hatfield, J.T.Yoke - Inorg. Chem. 1, 475(1962)

24 - L.Naldini-Gazz. Chim. Ital. 20, 391(1960)

25 - L.Naldini-Gazz. Chim. Ital. 20, 1337(1960)

26 - J.Chatt, G.J.Leight, D.M.P.Mingos, R.J.Paske - J.Chem. Soc. A,2636 (1968)

27 - J.Chatt, B.I.Shaw - J. Chem. Soc. 3466(1964)

28 - J.Chatt, A.E.Field, B.L.Shaw - J. Chem. Soc. 3371(1963) 
29 - J.Chatt, N.P.Johnson, B.L.Shaw - J. Chem. Soc. 2508(1964)

30 - J.Chatt, B.L.Shaw - Chem. Ind. 931 e 1386 (1960)

31 - F.G.Mann, A.F.Wells, D.Purdie - J. Chem. Soc. 1828(1937)

32 - R.C.Evans, F.G.Mann, H.S.Peiser, D.Purdie - J. Chem. Soc. 1209 (1940)

33 - G.Costa, E.Reisenhofer, L. Stefani - J. Inorg. Nucl. Chem. 27 , 2581 (1965)

34 - F.H.Jardine, F.J.Young - J. Chem. Soc. 2444 (1971)

35 - F. Glockling, K.A.Hooton - J. Chem. Soc. 2658 (1962)

36 - M.J.Schmelz, M.A.G.Hill, C.Curran - J. Phys. Chem. 65, 1273(1961)

37 - J.Chatt - J. Inorg. Nucl. Chem. 8, 515 (1957)

38 - J.Chatt, L.A.Duncanson, B.L.Shaw - Proc. Chem. Soc. 343 (1957); Chem. Ind. 859 (1958)

39 - J.Chatt, B.L.Shaw - Chem. Ind. 931 (1960)

40 - J.Chatt, B.L.Shaw - J. Chem. Soc. 285 (1961) e referências

41 - G.E.Coates, "Organometalic Compounds", Methuen, Londres, 1960, vol II, pág. 223

42 - M.Aresta, C.F.Nobile, M.Rossi, A.Sacco - Chem. Commun. 781 (1971); P.Giannocaro, M.Rossi, A.Sacco - Coord. Chem. Rev.- ㅇ, 77(1972)

43 - P.Rigo, A.Turco - Coord. Chem. Rev $\underline{8}$, 175(1972) e referências

44 - F.Basolo, J.Chatt, H.B.Gray, R.G.Pearson, B.L.Shaw - J.Chem. Soc. 2207 (1961)

45 - B.E.Mann, C.Masters, B.L.Shaw, R.E.Stainbank - Chem. Commun. 1103 (1971); V。 também J. Chem. Soc. A, 1079 (1967) e referências

46 - G.Booth - Adv. Inorg. Chem. and Radiochem. 6, I(1964)

47 - R.G.Pearson - J.Am. Chem. Soc. 85, 3533 (1964)

48 - F.Levi - "Aproveitamento Analítico da Extratibilidade de Compos tos de Adição de haletos de paládio e platina com fosfinas, arsinas e estibinas", Tese de Doutoramento - F.F.C.L.U.S.P. - 1965

49 - R.G.Cookson, F.G.Mann - J. Chem. Soc. 618(1947)

50. - F.G.Mann, I.T.Millar - J. Chem. Soc. 4453 (1952)

51 - P.Senise, F.Levi - Anal. Chim. Acta 30, 422 (1964)

52 - P.Senise, F.Levi - Anal. Chim. Acta 30, 509 (1964) 
53 - J.S.Forsythe, R.J.Magee, C.L.Wilson - Talanta 3, 324 e 330 (1960)

54 - R.Mc Alpine, B.A.Soule - "Qualitative Chemical Analysis (Prescott Johnson)", Van Nostrand, N.York, 1933, pág.465

55 - I.P.Alimarin, G.A.Zolotov - Talanta 2, 891 (1962)

56 - L.R.M.Pitombo - "Aplicação Analítica de Sulfetos, Selenetos e Teluretos Orgânicos - Identificação e Determinação de Paládio", Tese - Inst. Química U.S.P. - 1971

57 - R.G.Clem, E.H.Huffmann - Anal. Chem. 28, 926 (1966)

58 - A.V.Nikolaev,V.G.Torgov, E.N.Gilbert, V.A.Mikhailov, V.A. Pronin, L.G.Stadnikova, I.I.Kotlyarevskii - Izv. Sibirsk. Otd. Nauk. Ser. Khim. Nauk. 14 (6), 120 (1967)

59 - I.G.Yudelevich, G.A.Vall, V.G.Torgov, T.M.Korda - Zh. Anal. Khim. $\underline{25}, 870$ (1970)

60 - F:D.Sneel, C.T.Sneel - "Colorimetric Methods of Analysis", Van Nostrand, N. York, 1959

61 - D.F.Evans, D.Jones, G.Wilkinson - J. Chem. Soc. 3164 (1964)

62 - F.Feigl - "Spot Tests in Inorganic Analysis" (trad. ingl. R.E.Oes per) Elsevier, Amsterdam, 1958

63 - F.Feigl - Selecta Chimica 6, 1(1947)

64 - A.M.Schwapowalenko - Chem. Zentr. II (3), 588 (1930); citado nas referências 62 e 69

65 - F. Raschig - Ber 48, 2088 (1915)

66 - I.M.Koltoff, E.B.Sandell - "Textbook of Quantitative Inorganic Analysis", McMillan, N. Kork, 1952, pág 546

67 - A.scattergood - Inorganic Syntheses, 2, 87 (1946)

68 - B.M.Chadwick, A.G.Shape - Adv. Inorg. Chem. and Radiochem. 8,84 (1966)

69 - L.S.Bark, H.G.Higson - Analyst, 88, 751 (1963)

70 - A. Viehoever,C.0.Johns - J. Am. Chem. Soc. 37, 601 (1915)

71 - Referência 62, pág 276

72 - 0.A.Ohlweiler, J.0. Meditsch - Zh. Anal. Khim. 14, 30̈3 (1959); ci tado na referência 69

73 - O.A.Ohlweiler, J.O.Meditsch - Anal. Chem. 30, 451 (1958)

74 - A.A.Schilt - Anal. Chem. 30, 1409 (1958)

75 - M.W.Scoggins - Anal. Chem. 44, 1294 (1972)

76 - F.Feigl, H.E.Feigl - Anal. Chim. Acta 3, 300 (1949)

77 - P.Luis, C.N.Carducci, A.Sá - Mikrochim. Acta (Wien) 7 (1969) 
78 - R.E.Humphray, W.Hinze - Anal. Chem. 43, 1100 (1971)

79 - Y.Tanaka, S. Yamamoto - Japan Analyst 2, 8(1960); Anal.Abstr. 8 , 4546(1961); citado na referência 69

80 - W.Kielczewski, J. Tomkowiak - Chem. Anal. Warsaw 5, 889(1960); cị tado na referência 69

81 - F.Fiegl - "Specific and Special Reactions", Elsevier, N.York,1940; "Chemistry of Specific, Selective and Sensitive Reactions", Aca demic Press, N. York, 1949

82 - Referência 4I, capítulo IX

83 - A.J.Poe, M.S.Vaydia - J. Chem. Soc. 187(1960), 2981(1961)

84 - A.Ringbom - Z. Anal. Chem. 115, 385(1939)

85 - M.A.Schnepfe - Anal. Chim. Acta 58, 83(1972)

86 - S.Funahasi - Anal. Chim. Acta 57, 311(1971)

87 - H.Weisz, H.Ludwing - Anal. Chim. Acta 60, 385(1972)

88 - A.Peloso, G.Dolcetti, R. Ettore - Gazz. Chim. Ital. 27, 955(1967)

89 - A.Peloso, R.Ettore, G.Dolcetti - Inorg. Chim. Acta 1, 307 e 403(1967) e referências

90 - Y. Iamamoto, T.Tarumoto, M.Tsubouchi - Bull. Chem. Soc. Japan 44 , 2124(1971)

91 - E.J.Poziomek, D.W.Reger - Anal. Chim. Acta 58, 459(1972)

92 - J.K.Carlton - Anal. Chem. 22, 1072(1950)

93 - W.E.Cooley, D.H.Busch - Inorganic Syntheses 2, 209(1957)

94 - Referência 66, pág. 308

95 - W.Beck, W.P.Fehlhammer - Angew. Chem. 79, 146(1967); internat. ed. 6, 169 (1967)

96 - W.Beck, W.P.Fehlhammer, P.PBIlmann - Progress in Coordination Chemistry, Proceedings of the llth International Conference in Coordi nation Chemistry, Haifa, Jerusalem, Elsevier, 1968, pág 253

97 - W.Beck - Inorg. Nucl. Chem. Lett. 4, 143(1968)

98 - J.P.Collmann, M. Kubota, J.W.Hosking - J.Am. Chem. Soc. 89, 4809 (1967)

99 - W.Beck, K.Feldl - Angew. Chem. 77, 458(1965); internat. ed. 4, 439 (1965)

100-W.Beck, W.P.Fehlhammer, P.PBlmann, E.Schuierer, K.Feldl - Chem.Ber. 100, 2335(1967)

101- C.D.Alonso, L.R.M.Pİtombo - comunicação particular

102- A.H.Norbury, A.I.P.Sinha - Inorg. Nucl. Chem. Lett. 3, 355(1967) 
103- A.H.Norbury, A.I.P.Sinha - I. Chem. Soc. A 1598(1968)

104- L.M.Dennis, M.L.Nichols - "Gas Analysis", MacMillan, N.York,1929

105- H.Guérin - "Traité de Manipulation et d'Analyse des Gaz", Masson, Paris, 1952

106- M.Feldstein - J. Forensic Sci. 10, 35(1965)

107- G.Ciuhandu, A. Chicu - Fraes. Z. Anal. Chem. 255, 35(1971)

108- J.L.Lambert, P.A.Hamlin - Anal. Lett. 4 745(1971)

109- J.L.Lambert, R.R.Tschorn, P.A.Hamlin - Anal.Chem. 44 , 1529 (1972)

110- J.Lagrange, A.Avy - Mém. services chim. état (Paris) 39, 7(1954); citado na referência 60 . 


\section{INDICE GERAI}

Sumário

Introdução - COMPLEXOS MISTOS DE METAIS DE TRANSIÇAO COM HALETOS E FOSFINAS, ARSINAS, ESTIBINAS ......... I

Capítulo I - ESTUdos PRELIMINARES $\ldots \ldots \ldots \ldots \ldots \ldots \ldots \ldots \ldots \ldots \ldots$

A - Extratibilidade de Metais de Transição ............ 6

B - Possibilidades Analiticas .................... 9

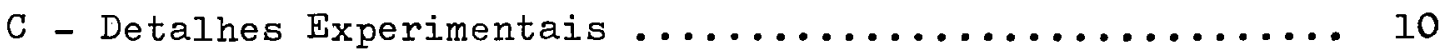

Capitulo II - IDENTIFICAÇÃO DE MICROQUANTIDADES DE CIANE

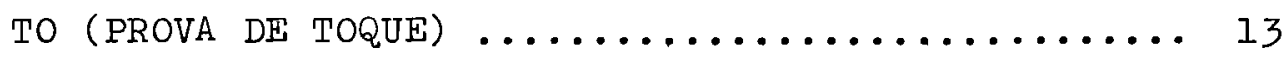

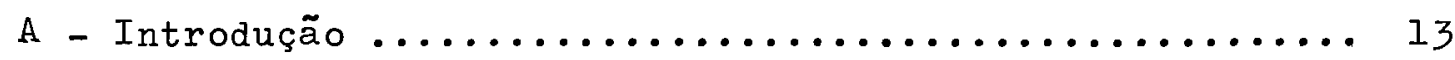

B - Papel-Reagente e sua Caracterização ............. 13

C - Elaboração do Procedimento e Estudo das Inter ferências .......................... 16

1 - Preparo do Papel-Reagente .............. 16

2 - Procedimento Básico ................... 17

3 - Anions Estranhos ................... 17

4 - Modificações do Procedimento Básico .......... 18

D - Detalhes Experimentais ........................ 18

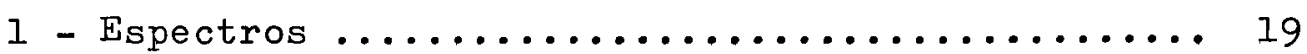

2 - Soluções e Reagentes .................... 20

E - Considerações Gerais ..................... 20

Capitulo III - EXTRAÇAO E DETERMINAÇR̃O ESPECTROFOTOMETRI CA DE IODETO ........................ 22

A - Estudo Sistemático e Extração Seletiva de Io-

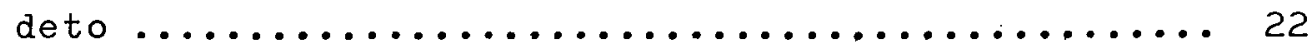


B - Condições da Reação. Composto Extraído ............ 23

1 - Espectro da Espécie Extraída .............. 25

2 - Compostos Extraídos a partir de plati-

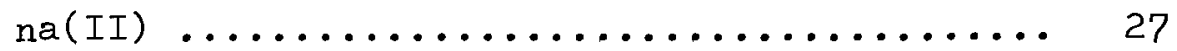

3 - Influência da concentração de trifenil estibina na fase orgânica ............. 27

4 - Influência da acidez da fase aquosa ......... 29

5 - Influência da concentração de platina ........ 29

6 - Influência do tempo de equilíbrio en tre as fases ....................... 30

7 - Eficiência da Extração .................. 31

C - Curva Padrão. Faixa de Trabalho e Precisão.

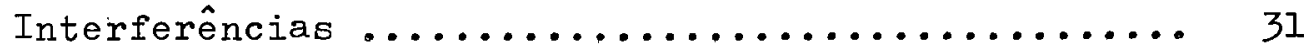

1 - Verificação da Lei de Lambert-Beer .......... 31

2 - Gráfico de Ringbom ................... 31

3 - Precisão das Medidas .................... 32

4 - Determinação de Iodeto na presença de

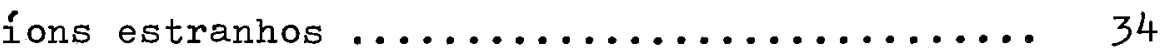

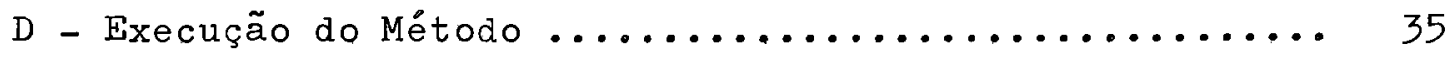

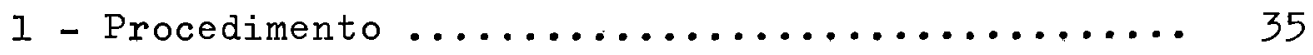

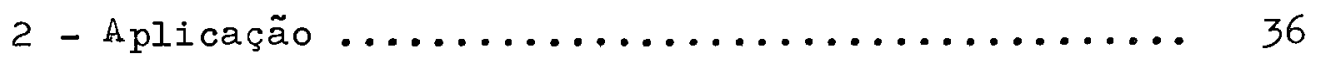

E - Detalhes Experimentais .................. 36

1 - Espectros e Medidas Espectrofotométricas ............................. 36

2 - Preparação de $\mathrm{PtCl}_{2} \ldots \ldots \ldots \ldots \ldots \ldots \ldots \ldots \ldots \ldots . \ldots \ldots$

3 - Soluções e Reagentes ................... 37

4 - Agitação Mecânica ................... 37

F - Considerações Gerais ..................... 37 
Capítulo IV - COLETA E DOSAGEM DE MONOXIDO DE CARBONO .......... 39

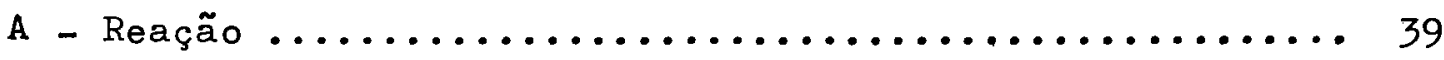

B - Caracterização dos Compostos ................. 39

C - Medidas Espectrofotométricas no UV .............. 41

1 - Espectros Diferenciais ................ 41

2 - Curva Padrão ....................... 44

3 - Precisão das Medidas ................... 44

D - Procedimento ......................... 46

E - Detalhes Experimentais ..................... 47

1 - Aparelhagem, Padrões. Técnica de Coleta ...... 47

2 - Preparações ........................ 49

3 - Medidas Espectrofotométricas ............. 49

$F$ - Considerações Gerais .................... 50

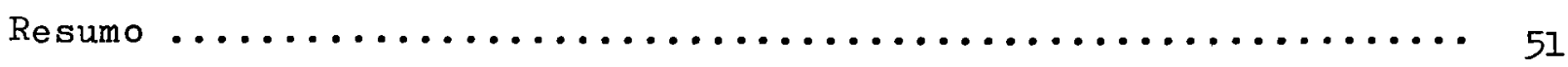

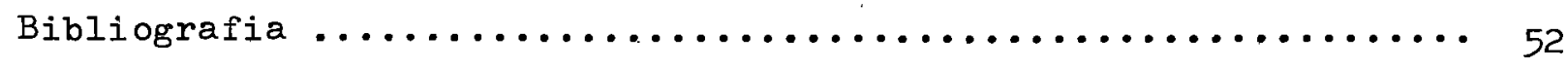

Indice Geral $\ldots \ldots \ldots \ldots \ldots \ldots \ldots \ldots \ldots \ldots \ldots \ldots \ldots \ldots \ldots \ldots \ldots \ldots$ 